\title{
Study of the System Barium Oxide-Aluminum Oxide-Water at $30^{\circ} \mathrm{C}$
}

\author{
By Elmer T. Carlson, Thomas J. Chaconas, and Lansing S. Wells \\ A study has been made of the action of water and of barium hydroxide solutions \\ on the following compounds: $\mathrm{BaO} \cdot \mathrm{Al}_{2} \mathrm{O}_{3}, 3 \mathrm{BaO} \cdot \mathrm{Al}_{2} \mathrm{O}_{3}, \mathrm{BaO} \cdot \mathrm{Al}_{2} \mathrm{O}_{3} \cdot \mathrm{H}_{2} \mathrm{O}, \mathrm{BaO} \cdot \mathrm{Al}_{2} \mathrm{O}_{3} \cdot 2 \mathrm{H}_{2} \mathrm{O}$, \\ $\mathrm{BaO} . \mathrm{Al}_{2} \mathrm{O}_{3} .4 \mathrm{H}_{2} \mathrm{O}, \mathrm{BaO} . \mathrm{Al}_{2} \mathrm{O}_{3} .7 \mathrm{H}_{2} \mathrm{O}, 7 \mathrm{BaO} .6 \mathrm{Al}_{2} \mathrm{O}_{3} .36 \mathrm{H}_{2} \mathrm{O}, 2 \mathrm{BaO} . \mathrm{Al}_{2} \mathrm{O}_{3} .5 \mathrm{H}_{2} \mathrm{O}$, and $\mathrm{Al}_{2} \mathrm{O}_{3} .3 \mathrm{H}_{2} \mathrm{O}$. \\ From this, together with a study of precipitation from supersaturated barium aluminate \\ solutions, a diagram of phase equilibria (stable and metastable) at $30^{\circ} \mathrm{C}$ has been drawn. \\ All the barium aluminates are hydrolyzed by water. The stable solid phases in the system \\ $\mathrm{BaO}-\mathrm{Al}_{2} \mathrm{O}_{3}-\mathrm{H}_{2} \mathrm{O}$ at $30^{\circ} \mathrm{C}$ are $\mathrm{Al}_{2} \mathrm{O}_{3} .3 \mathrm{H}_{2} \mathrm{O}$ (gibbsite), $\mathrm{Ba}(\mathrm{OH})_{2} .8 \mathrm{H}_{2} \mathrm{O}$, and, over a narrow \\ range, probably $2 \mathrm{BaO} \cdot \mathrm{Al}_{2} \mathrm{O}_{3} .5 \mathrm{H}_{2} \mathrm{O}$. With the exception of the two lowest hydrates, all \\ the hydrated barium aluminates possess a range of metastable solubility.
}

\section{Introduction}

Although the calcium aluminates, because of their relationship to hydraulic cements, have been the subject of numerous investigations here and elsewhere during recent years, the barium aluminates have been somewhat neglected. The latter, at present, are of limited practical importance. They have been used to some extent in water softening $[1],{ }^{1}$ and they may be formed as intermediate products in the conversion of barium minerals to other compounds $[2,3]$. It has been shown [4] that $\mathrm{BaO} \cdot \mathrm{Al}_{2} \mathrm{O}_{3}$ possesses binding properties. Hunt and Temin [5] reported some experiments with barium aluminate relative to its suitability as a wall plaster for protection against X-rays, but no details as to preparation or composition of the aluminate were given. Attempts have also been made to prepare barium cement, analogous to portland cement, by substituting barium carbonate, in whole or in part, for calcium carbonate in the raw mix. It has recently been reported by Gallo [17] and by Braniski [19] that such substitution is feasible, and that the resulting cement is particularly resistant to sea water and to sulfate waters.

The purpose of the present investigation was twofold. First, to study the hydration of the barium aluminates; and second, to discover what analogies, if any, exist between the aluminates of barium and those of calcium, in the hope that this might aid in clarifying some aspects of the hydration of the calcium aluminates that are not completely understood.

A number of anhydrous barium aluminates are reported in the literature, but only three may be considered definitely established, namely, $3 \mathrm{BaO} \cdot \mathrm{Al}_{2} \mathrm{O}_{3}$, $\mathrm{BaO} \cdot \mathrm{Al}_{2} \mathrm{O}_{3}$, and $\mathrm{BaO} \cdot 6 \mathrm{Al}_{2} \mathrm{O}_{3}[6,7,8,9]$. The last is believed to be analogous to $\beta$-alumina $[10,11]$, and its exact composition appears to be somewhat in doubt [8]. It was not included in the present study.

The various barium aluminate hydrates have been described in a previous paper [12]. No evidence of any hydrate more basic than $2 \mathrm{BaO} . \mathrm{Al}_{2} \mathrm{O}_{3} .5 \mathrm{H}_{2} \mathrm{O}$ was found in the present study, although Beckmann [13] and Maekawa $[14,15]$ have reported the preparation of a tribarium aluminate hydrate. Neither optical

${ }^{1}$ Figures in brackets indicate the literature references at end of this paper. properties nor X-ray diffraction data, however, were given. Malquori [16] has published a phase equilibrium diagram of the system $\mathrm{BaO}-\mathrm{Al}_{2} \mathrm{O}_{3}-\mathrm{H}_{2} \mathrm{O}$ at $20^{\circ} \mathrm{C}$.

The present investigation includes a study of the action of water and of barium hydroxide solutions on the various aluminates and a diagram of phase equilibria in the system at $30^{\circ} \mathrm{C}$.

\section{Preparation of Compounds}

\section{Raw Materials}

The alumina used in the preparation of the various aluminates was a commercial preparation of gibbsite $\left(\mathrm{Al}_{2} \mathrm{O}_{3} \cdot 3 \mathrm{H}_{2} \mathrm{O}\right)$ used in the manufacture of glass. It contained about 0.30 percent of $\mathrm{Na}_{2} \mathrm{O}$; other impurities were negligible. Barium was obtained in the form of the carbonate, the hydroxide, and (for a few experiments) the nitrate. These were reagent quality chemicals meeting ACS standards.

\section{2. $\mathrm{BaO} \cdot \mathrm{Al}_{2} \mathrm{O}_{3}$}

Barium carbonate and gibbsite were blended in the correct proportions, made up to a thin paste with water containing a few drops of a dispersing agent, and thoroughly mixed. The paste was then dried and heated in a platinum dish at $1,400^{\circ} \mathrm{C}$ for $1 \mathrm{hr}$. The product was shown by petrographic examination and X-ray diffraction analysis to be essentially monobarium aluminate $\left(\mathrm{BaO} \cdot \mathrm{Al}_{2} \mathrm{O}_{3}\right)$. Treatment with hydrochloric acid left a residue amounting to 0.7 percent, probably consisting of corundum. Attempts to improve the product by grinding and reheating were unsuccessful. Lower burning temperatures were found to be unsatisfactory; for example, a batch heated for $1 \mathrm{hr}$ at $1,300^{\circ}$ had an insoluble residue of 8.5 percent.

\section{3. $3 \mathrm{BaO} \cdot \mathrm{Al}_{2} \mathrm{O}_{3}$}

Tribarium aluminate was prepared in the manner described above for monobarium aluminate, with the appropriate change in proportion of raw materials. The mixture was heated in a refractory crucible, as experience showed that platinum was strongly 
attacked. A temperature of $1,300^{\circ}$ was found to be adequate to reduce the insoluble residue to 0.1 percent. For some of the tests, the product was subsequently fused in an oxygen blast.

\section{4. $\mathrm{BaO} \cdot \mathrm{Al}_{2} \mathrm{O}_{3} \cdot \mathrm{H}_{2} \mathrm{O}$}

The compound to which the formula $\mathrm{BaO} \cdot \mathrm{Al}_{2} \mathrm{O}_{3}$.$\mathrm{H}_{2} \mathrm{O}$ is assigned was prepared hydrothermally. Gibbsite and barium hydroxide were mixed in the required proportion, with added water, and placed in platinum dishes that were then stacked in a bombtype autoclave and heated in an oven at about $260^{\circ} \mathrm{C}$ for 7 days. The product in each of the dishes consisted of a hard crust of the desired hydrate surrounding a core of softer material. The latter was shown by X-ray analysis to consist of boehmite $\left(\mathrm{Al}_{2} \mathrm{O}_{3} \cdot \mathrm{H}_{2} \mathrm{O}\right)$. Despite this evidence of the presence of excess alumina, the molar ratio of $\mathrm{BaO}$ to $\mathrm{Al}_{2} \mathrm{O}_{3}$ in the aluminate ranged from 1.10 to 1.14 , in agreement with the findings previously published [12]. It appears likely that the actual formula should be $8 \mathrm{BaO} .7 \mathrm{Al}_{2} \mathrm{O}_{3} .7 \mathrm{H}_{2} \mathrm{O}$ or $9 \mathrm{BaO}_{2} 8 \mathrm{Al}_{2} \mathrm{O}_{3} .8 \mathrm{H}_{2} \mathrm{O}$, but it would be impossible to establish either formula on the basis of present data. All preparations of this hydrate, regardless of changes in raw materials and in conditions of heating, have been more or less contaminated with minute inclusions of some unknown material in the crystals.

\section{5. $\mathrm{BaO} \cdot \mathrm{Al}_{2} \mathrm{O}_{3} \cdot 2 \mathrm{H}_{2} \mathrm{O}$}

Monobarium aluminate dihydrate, $\mathrm{BaO} \cdot \mathrm{Al}_{2} \mathrm{O}_{3}$.$2 \mathrm{H}_{2} \mathrm{O}$, was prepared by the method described above for $\mathrm{BaO} \cdot \mathrm{Al}_{2} \mathrm{O}_{3} \cdot \mathrm{H}_{2} \mathrm{O}$, except that the temperature was held at about $215^{\circ} \mathrm{C}$, and the duration of heating was 4 days. The product consisted of well-formed crystals, ranging up to $3 \mathrm{~mm}$ in size. Apparently there was a small amount of uncombined alumina, as the molar ratio, $\mathrm{BaO}: \mathrm{Al}_{2} \mathrm{O}_{3}: \mathrm{H}_{2} \mathrm{O}$, was found to be 0.95:1:1.95, and a slight turbidity remained when the crystals were dissolved in hydrochloric acid.

\section{6. $\mathrm{BaO} \cdot \mathrm{Al}_{2} \mathrm{O}_{3} \cdot 4 \mathrm{H}_{2} \mathrm{O}$}

Several small batches of monobarium aluminate tetrahydrate, $\mathrm{BaO} \cdot \mathrm{Al}_{2} \mathrm{O}_{3} .4 \mathrm{H}_{2} \mathrm{O}$, prepared by various means, were used in the solubility studies. Some were prepared by allowing $\mathrm{BaO} \cdot \mathrm{Al}_{2} \mathrm{O}_{3} .7 \mathrm{H}_{2} \mathrm{O}$ to stand, in contact with barium aluminate solution, for several months at $30^{\circ} \mathrm{C}$. The usual procedure, however, was to raise the temperature to $50^{\circ} \mathrm{C}$, whereby the transition period was shortened to a few days. In all cases, the analysis of the products was very close to the theoretical.

\section{7. $\mathrm{BaO} \cdot \mathrm{Al}_{2} \mathrm{O}_{3} \cdot 7 \mathrm{H}_{2} \mathrm{O}$ and $7 \mathrm{BaO} \cdot 6 \mathrm{Al}_{2} \mathrm{O}_{3} \cdot 36 \mathrm{H}_{2} \mathrm{O}$}

Monobarium aluminate heptahydrate (BaO.$\left.\mathrm{Al}_{2} \mathrm{O}_{3} .7 \mathrm{H}_{2} \mathrm{O}\right)$ and the compound $7 \mathrm{BaO} .6 \mathrm{Al}_{2} \mathrm{O}_{3} .36 \mathrm{H}_{2} \mathrm{O}$ are close together in composition but quite dissimilar in optical properties. In a previous publication [12], the latter compound was designated 1.1BaO.$\mathrm{Al}_{2} \mathrm{O}_{3} \cdot 6 \mathrm{H}_{2} \mathrm{O}$. They were prepared by precipitation from supersaturated solutions. These solutions were prepared in various ways, the most satisfactory being agitation of anhydrous $\mathrm{BaO} \cdot \mathrm{Al}_{2} \mathrm{O}_{3}$ with $\mathrm{Ba}(\mathrm{OH})_{2}$ solution for $1 \mathrm{hr}$, followed by filtration. By this method, solutions containing as high as $35 \mathrm{~g}$ of $\mathrm{Al}_{2} \mathrm{O}_{3}$ per liter were obtained. Solutions of lower concentration were prepared somewhat more conveniently by the action of boiling barium hydroxide solution on gibbsite. Best results were obtained by using $75 \mathrm{~g}$ of gibbsite, $125 \mathrm{~g}$ of $\mathrm{Ba}(\mathrm{OH})_{2} \cdot 8 \mathrm{H}_{2} \mathrm{O}$, and 1 liter of water, boiling for $1 \frac{1 / 2}{h}$ hrs, filtering at once, and allowing to cool. Concentrations ranging from 11 to nearly $19 \mathrm{~g}$ of $\mathrm{Al}_{2} \mathrm{O}_{3}$ per liter were obtained by this method.

The course of precipitation varied somewhat with concentration. From highly concentrated solutions, $7 \mathrm{BaO} .6 \mathrm{Al}_{2} \mathrm{O}_{3} \cdot 36 \mathrm{H}_{2} \mathrm{O}$ began to separate almost at once, while from more dilute solutions the start of precipitation was sometimes delayed several days. After a period ranging from a few days to 4 mos, the solid phase underwent a transformation to $\mathrm{BaO}$.$\mathrm{Al}_{2} \mathrm{O}_{3} .7 \mathrm{H}_{2} \mathrm{O}$, probably by means of re-solution and reprecipitation, as no intermediate forms were observed, This phase change occurred when the concentration of alumina had been lowered to a rather poorly established range indicated by the dotted line in figure $10.7 \mathrm{BaO}^{2} 6 \mathrm{Al}_{2} \mathrm{O}_{3} \cdot 36 \mathrm{H}_{2} \mathrm{O}$ appears to be progressively more stable as the $\mathrm{BaO}$ concentration is increased. Solutions having initial concentrations below or only slightly above the dotted line in figure 10 yielded $\mathrm{BaO} \cdot \mathrm{Al}_{2} \mathrm{O}_{3} \cdot 7 \mathrm{H}_{2} \mathrm{O}$ as the primary crystalline phase.

Considerable work was done in an effort to establish the composition of these hydrates. In the case of $\mathrm{BaO} \cdot \mathrm{Al}_{2} \mathrm{O}_{3} \cdot 7 \mathrm{H}_{2} \mathrm{O}$, analysis of numerous preparations gave values ranging from 6 to 7 moles of $\mathrm{H}_{2} \mathrm{O}$ per mole of $\mathrm{Al}_{2} \mathrm{O}_{3}$. The following experiment throws some light on the question. A preparation of the hydrate was filtered, washed lightly with water, and divided into two portions, one of which was stored in a desiccator over calcium chloride, the other over a saturated solution of ammonium chloride (relative humidity about $79 \%$ ). After 11 days, both samples had reached constant weight. The molar ratio $\mathrm{H}_{2} \mathrm{O}: \mathrm{Al}_{2} \mathrm{O}_{3}$ was 6.25 in the sample dried over calcium chloride, 6.96 in the one dried at the higher humidity. It is inferred that the formula is $\mathrm{BaO} \cdot \mathrm{Al}_{2} \mathrm{O}_{3} \cdot 7 \mathrm{H}_{2} \mathrm{O}$, and that 1 molecule of water is so loosely bound that it is easily given off in dry air. The hydrate is completely broken down at $120^{\circ} \mathrm{C}$ [12].

In the case of the hydrate previously designated $1.1 \mathrm{BaO} \cdot \mathrm{Al}_{2} \mathrm{O}_{3} \cdot 6 \mathrm{H}_{2} \mathrm{O}[12]$, the chief uncertainty is in the ratio of $\mathrm{BaO}$ to $\mathrm{Al}_{2} \mathrm{O}_{3}$. Analysis of numerous preparations gave ratios ranging from 1.12 to 1.16 , with no apparent trend toward higher values from solutions richer in $\mathrm{BaO}$ (as would be the case if it were a question of solid solution). On the basis of these analyses the formula $7 \mathrm{BaO} .6 \mathrm{Al}_{2} \mathrm{O}_{3} .36 \mathrm{H}_{2} \mathrm{O}$ has been tentatively assigned to this compound.

\section{8. $2 \mathrm{BaO} \cdot \mathrm{Al}_{2} \mathrm{O}_{3} \cdot 5 \mathrm{H}_{2} \mathrm{O}$}

The most basic of the barium aluminate hydrates found in this study is $2 \mathrm{BaO} \cdot \mathrm{Al}_{2} \mathrm{O}_{3} \cdot 5 \mathrm{H}_{2} \mathrm{O}$. Several 
small batches of this were prepared by boiling a mixture of gibbsite and barium hydroxide solution until crystallization commenced, then filtering the solution and concentrating the filtrate by further boiling. The compound separated out in coarsely crystalline form and was readily washed by decantation. In all cases the analyses were close to the theoretical composition. Attempts to prepare a more basic hydrate were unsuccessful.

\section{Reactions with Water and with Barium Hydroxide Solutions}

\section{General Procedure}

Preliminary experiments were performed to ascertain the quantities of the various compounds that might be expected to go into solution. A moderate excess of solid material was then used in subsequent experiments. The compound being studied was ground, if necessary, to 100-mesh or finer, and placed in an Erlenmeyer flask of appropriate size, and the flask was then nearly filled with water or with barium hydroxide solution of the desired strength. The flask was then tightly stoppered, shaken frequently until there was no longer any danger of "setting", and then stored in a cabinet maintained at $30^{\circ} \mathrm{C}$. The cabinet was equipped with a recording thermometer. No provision was made for cooling the air, so that in summer the temperature regularly exceeded $30^{\circ} \mathrm{C}$. This deviation did not materially affect the experiments described below but of course could not be tolerated for the equilibrium determinations described in section III, 11. Consequently, the latter tests were made during cooler weather. The normal fluctuation in temperature of the air in the cabinet was about $\pm 0.2^{\circ} \mathrm{C}$, but it was undoubtedly much less within the flasks.

The flasks were shaken at intervals. From time to time, samples of the clear liquid (5 or $10 \mathrm{ml}$ ) were pipetted out and analyzed for $\mathrm{Al}_{2} \mathrm{O}_{3}$ and $\mathrm{BaO}$ by standard analytical methods. Alumina was precipitated by ammonium hydroxide, $\mathrm{BaO}$ by sulfuric acid. At the same time, in most cases, a drop of the liquid containing particles of the solid phase or phases present was removed by means of a small pipette, placed on a slide, and examined under the microscope. In this way, phase changes were readily detected.

In experiments dealing with the anhydrous aluminates the reactions were very rapid at first, and the intervals between samplings were too brief to permit clarification by settling. It was therefore necessary to filter off portions of the solutions for analysis. The liquid was filtered through a fritted glass crucible by means of suction and caught in a small test tube inside the filter flask. In this way, the solution was exposed to the air only very briefly, and carbonation was negligible.

In the tables that follow, it will be noted that the values for $\mathrm{BaO}$ are given to the nearest tenth of 1 percent, although those for $\mathrm{Al}_{2} \mathrm{O}_{3}$ are carried to hundredths. In the majority of cases this results in three significant figures, which is believed to be the limit of precision in sampling with a 10-ml pipette. Initial concentration values enclosed in parentheses were calculated from mixing proportions, rather than determined by analysis.

\section{2. $\mathrm{BaO} \cdot \mathrm{Al}_{2} \mathrm{O}_{3}$}

The results of a series of experiments with monobarium aluminate $\left(\mathrm{BaO} \cdot \mathrm{Al}_{2} \mathrm{O}_{3}\right)$ are given in table 1 and figure 1. Experiments 1-1, 1-2, and 1-3 were designed to show the action of water on the aluminate. To avoid confusion, $1-1$ and 1-3 are not included in figure 1 . In experiment $1-1$, table $1,15 \mathrm{~g}$ of the dry aluminate was shaken with $300 \mathrm{ml}$ of water. The data show that it dissolved rather rapidly, attaining a concentration of $17.40 \mathrm{~g}$ of $\mathrm{Al}_{2} \mathrm{O}_{3}$ per liter at $1 \mathrm{hr}$. This is equivalent to roughly 85 percent of the material originally present. Precipitation of amorphous hydrated alumina was appreciable at $1 \mathrm{hr}$, slightly greater at 1 day, and very pronounced at 3 days, as shown by the sharp drop in $\mathrm{Al}_{2} \mathrm{O}_{3}$ concentration, while the $\mathrm{BaO}$ remained practically constant.

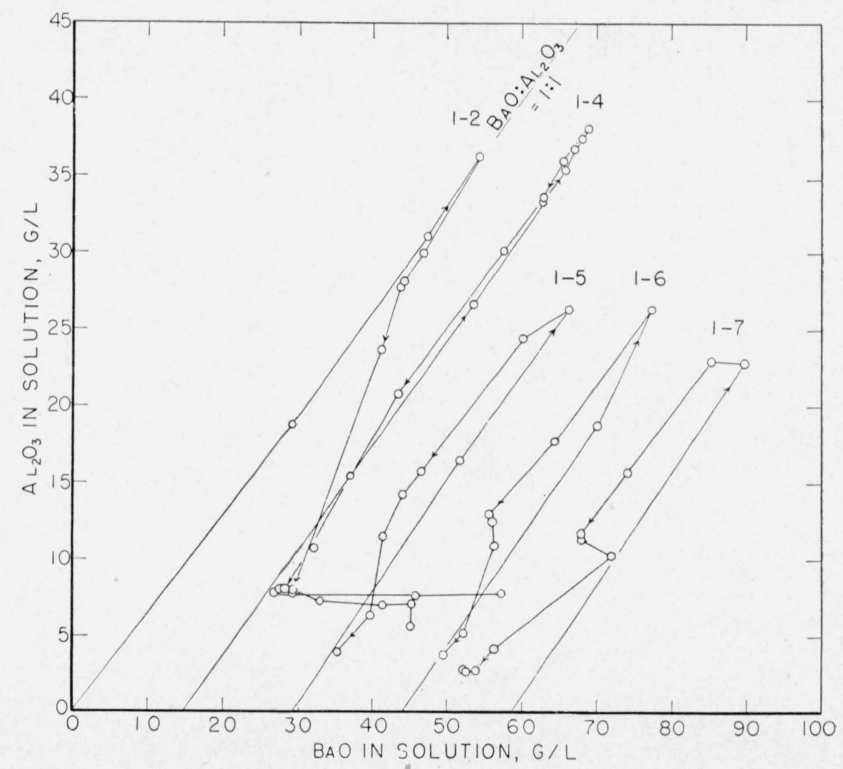

Figure 1. Solubility of $\mathrm{BaO} \cdot \mathrm{Al}_{2} \mathrm{O}_{3}$ in water and in barium hydroxide solutions at $30^{\circ} \mathrm{C}$.

For the rest of the experiments, the proportion of the anhydrous aluminate was increased to 25 or 30 $\mathrm{g} / 300 \mathrm{ml}$ of water (or solution). In No. 1-2, maximum concentration was reached in $1 \mathrm{hr}$. The ascending curve in figure 1 has a slope corresponding closely to a molar $\mathrm{BaO}: \mathrm{Al}_{2} \mathrm{O}_{3}$ ratio of $1: 1$, and reaches a point in excess of $36 \mathrm{~g}$ of $\mathrm{Al}_{2} \mathrm{O}_{3}$ per liter. Examination of the table shows that not one but three separate maxima were found, at 1,2, and 6 hours, respectively. For the sake of clarity some of these points are omitted from the graph in figure 1. The concentration fluctuated up and down, very close to the $1: 1$ ratio line, during this period. By way of confirma- 
TABLE 1. Solubitity of $\mathrm{BaO} \cdot \mathrm{Al}_{2} \mathrm{O}_{3}$ in water and in barium hydroxide solutions at $30^{\circ} \mathrm{C}$

\begin{tabular}{|c|c|c|c|}
\hline \multirow{2}{*}{ Time } & \multicolumn{2}{|c|}{$\begin{array}{c}\text { Concentration of } \\
\text { solution }\end{array}$} & \multirow{2}{*}{ Solid phases present } \\
\hline & $\mathrm{A}_{2} \mathrm{O}_{3}$ & $\mathrm{BaO}$ & \\
\hline \multicolumn{4}{|r|}{ Experiment 1-1 a } \\
\hline 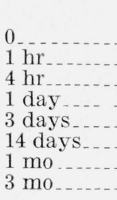 & $\begin{array}{l}\text { g/liter } \\
0 \\
17.40 \\
17.65 \\
17.40 \\
7.30 \\
4.25 \\
3.80 \\
3.40\end{array}$ & $\begin{array}{c}\text { g/liter } \\
0 \\
26.5 \\
27.5 \\
27.8 \\
28.0 \\
27.9 \\
28.0 \\
28.2\end{array}$ & $\begin{array}{l}\mathrm{BaO} \cdot \mathrm{Al}_{2} \mathrm{O}_{3} . \\
\mathrm{BaO} \cdot \mathrm{Al}_{2} \mathrm{O}_{3}+\text { hyd. } \quad \mathrm{Al}_{2} \mathrm{O}_{3} . \\
\mathrm{Hyd} . \mathrm{Al}_{2} \mathrm{O}_{3} . \\
\text { Do. } \\
\text { Do. } \\
\text { Do. } \\
\text { Do. }\end{array}$ \\
\hline \multicolumn{4}{|r|}{ Experiment 1-2 } \\
\hline 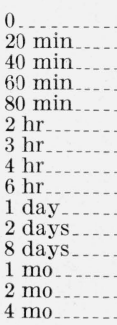 & $\begin{array}{r}0 \\
18.80 \\
31.12 \\
36.30 \\
26.62 \\
30.00 \\
28.22 \\
27.10 \\
27.78 \\
23.70 \\
8.02 \\
7.30 \\
7.00 \\
7.10 \\
5.70\end{array}$ & $\begin{array}{l}0 \\
29.0 \\
47.3 \\
54.4 \\
41.0 \\
46.7 \\
44.2 \\
42.5 \\
43.7 \\
41.1 \\
29.2 \\
32.8 \\
41.3 \\
45.1 \\
45.1\end{array}$ & $\begin{array}{l}\mathrm{BaO} . \mathrm{Al}_{2} \mathrm{O}_{3} \\
\mathrm{BaO} . \mathrm{Al}_{2} \mathrm{O}_{3}+\text { hyd. } \mathrm{Al}_{2} \mathrm{O}_{3} . \\
\text { Do. } \\
\text { Do. } \\
\text { Do. } \\
\text { Do. } \\
\text { Do. } \\
\text { Do. } \\
\text { Do. } \\
\text { Do. } \\
\mathrm{Hyd} \mathrm{Al}_{2} \mathrm{O}_{3}+\mathrm{BaO} . \mathrm{Al}_{2} \mathrm{O}_{3} .7 \mathrm{H}_{2} \mathrm{O} . \\
\text { Do. } \\
\text { Do. } \\
\text { Do. } \\
\mathrm{Hyd} . \mathrm{Al}_{2} \mathrm{O}_{3} .\end{array}$ \\
\hline
\end{tabular}

\begin{tabular}{|c|c|c|c|}
\hline \multicolumn{4}{|c|}{ Experiment 1-3 a } \\
\hline ..... & 0 & 0 & $\mathrm{BaO} \cdot \mathrm{Al}_{2} \mathrm{O}_{3}$. \\
\hline $40 \mathrm{~min}$ & 25.90 & 39.7 & Do. \\
\hline $50 \mathrm{~min}$ & 27.90 & 43.0 & Do. \\
\hline $60 \mathrm{~min} . . .$. & 26.70 & 40.6 & Do. \\
\hline $70 \mathrm{~min}$ & 30.82 & 46.5 & Do. \\
\hline $80 \mathrm{~min}$ & 29.54 & 44.1 & $\mathrm{BaO} . \mathrm{Al}_{2} \mathrm{O}_{3}+$ hyd. ${ }^{-} \mathrm{Al}_{2} \mathrm{O}_{3}$. \\
\hline $90 \mathrm{~min}$ & 30.62 & 45.5 & Do. \\
\hline $100 \mathrm{~min}$ & 29.38 & 44.5 & Do. \\
\hline $2 \mathrm{hr} \ldots \ldots$ & 28.34 & 43.2 & Do. \\
\hline $3 \mathrm{hr} \ldots . . .$. & 30.70 & 46.8 & Do. \\
\hline $7 \mathrm{hr} \ldots \ldots$. & 28.36 & 45. 2 & Do. \\
\hline 1 day & 16. 76 & 32.1 & $\mathrm{Hyd} . \mathrm{Al}_{2} \mathrm{O}_{3}+\mathrm{BaO} \cdot \mathrm{Al}_{2} \mathrm{O}_{3} .7 \mathrm{H}_{2} \mathrm{O}$. \\
\hline 7 days..... & 7. 20 & 32.5 & Do. \\
\hline $1 \mathrm{mo} \ldots \ldots$ & 7.00 & 41.3 & Do. \\
\hline $4 \mathrm{mo}_{\ldots} \ldots$ & 6.10 & 47. 9 & Hyd. $\mathrm{Al}_{2} \mathrm{O}_{3}+\mathrm{BaO} \cdot \mathrm{Al}_{2} \mathrm{O}_{3} .4 \mathrm{H}_{2} \mathrm{O}$. \\
\hline
\end{tabular}

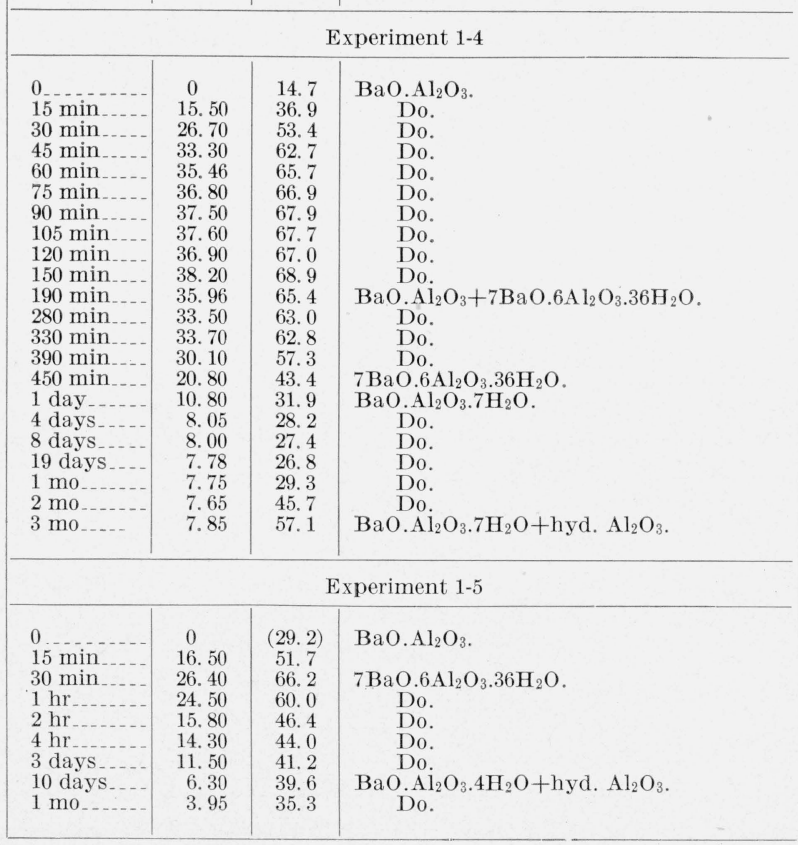

a Not plotted in figure 1 .
TABLE 1. Solubility of $\mathrm{BaO} \cdot \mathrm{Al}_{2} \mathrm{O}_{3}$ in water and in barium. hydroxide solutions at $30^{\circ} \mathrm{C}$-Continued

\begin{tabular}{|c|c|c|c|}
\hline \multirow{2}{*}{ Time } & \multicolumn{2}{|c|}{$\begin{array}{l}\text { Concentration of } \\
\text { solution }\end{array}$} & \multirow{2}{*}{ Solid phases present } \\
\hline & $\mathrm{A}_{2} \mathrm{O}_{3}$ & $\mathrm{BaO}$ & \\
\hline \multicolumn{4}{|c|}{ Experiment 1-6 } \\
\hline 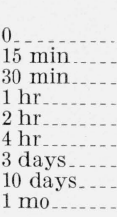 & $\begin{array}{c}\text { giliter } \\
0 \\
18.84 \\
26.49 \\
17.90 \\
13.10 \\
12.50 \\
10.86 \\
5.25 \\
3.81\end{array}$ & $\begin{array}{c}\text { o/liter } \\
(43.9) \\
70.1 \\
77.3 \\
64.3 \\
55.5 \\
55.9 \\
56.2 \\
52.0 \\
49.5\end{array}$ & $\begin{array}{l}\mathrm{BaO} \cdot \mathrm{Al}_{2} \mathrm{O}_{3} . \\
7 \mathrm{BaO} .6 \mathrm{Al}_{2} \mathrm{O}_{3} .36 \mathrm{H}_{2} \mathrm{O} . \\
7 \mathrm{BaO} .6 \mathrm{Al}_{2} \mathrm{O}_{3} .36 \mathrm{H}_{2} \mathrm{O} . \\
7 \mathrm{BaO} .6 \mathrm{Al}_{2} \mathrm{O}_{3} .36 \mathrm{H}_{2} \mathrm{O}+\mathrm{BaO} . \mathrm{Al}_{2} \mathrm{O}_{3} .4 \mathrm{H}_{2} \mathrm{O} . \\
\mathrm{BaO} . \mathrm{Al}_{2} \mathrm{O}_{3} .4 \mathrm{H}_{2} \mathrm{O} . \\
\quad \text { Do. }\end{array}$ \\
\hline \multicolumn{4}{|c|}{ Experiment 1-7 } \\
\hline $\begin{array}{l}0 \\
15 \mathrm{~min} \\
30 \mathrm{~min} \\
1 \mathrm{hr} \\
2 \mathrm{hr} \\
4 \mathrm{hr} \\
3 \text { days } \\
10 \text { days............. } \\
1 \mathrm{mo} \\
2 \mathrm{mo} \\
4 \mathrm{mo} \\
5 \mathrm{mo}\end{array}$ & $\begin{array}{r}0 \\
22.86 \\
23.00 \\
15.70 \\
11.80 \\
11.40 \\
10.34 \\
4.23 \\
2.85 \\
2.77 \\
2.88 \\
2.75\end{array}$ & \begin{tabular}{l|l}
$(58.5)$ \\
89.7 \\
85.3 \\
74.0 \\
67.9 \\
67.8 \\
71.9 \\
56.3 \\
53.8 \\
52.5 \\
52.0 \\
52.3
\end{tabular} & 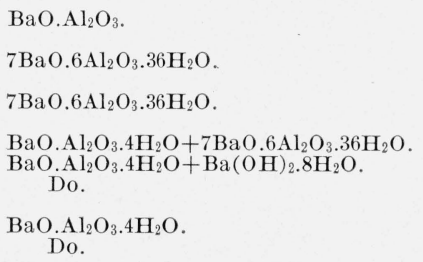 \\
\hline
\end{tabular}

tion of this unexpected finding, the experiment was repeated, with samples taken at shorter intervals (experiment No. 1-3 in table 1). This time four maxima were found, at 50, 70, and $90 \mathrm{~min}$., and 3 $\mathrm{hr}$, respectively, and again the concentration varied up and down along the 1:1 line. Although the actual mechanism of this process could not be determined, a partial explanation may be advanced. When the anbydrous aluminate is agitated with water it dissolves rapidly at first, but the rate of solution decreases as the concentration rises and the amount of undissolved solid diminishes. Precipitation of a new solid phase, or phases, commences as soon as a sufficiently high concentration has been reached and proceeds at an increasing rate for some time. Eventually the point is reached at which the two processes of solution and precipitation are equal. For some reason, in these experiments, they failed to remain in balance; instead, first one and then the other predominated. The fact that the concentration moved downward as well as upward along the 1:1 ratio line suggests that the precipitating phase must have been $\mathrm{BaO} . \mathrm{Al}_{2} \mathrm{O}_{3} .7 \mathrm{H}_{2} \mathrm{O}$. None of this phase was actually observed at this stage, but the undissolved grains of $\mathrm{BaO} \cdot \mathrm{Al}_{2} \mathrm{O}_{3}$ were seen to be coated with a thin layer of extremely fine birefringent crystals, too small for identification. It is assumed that these were $\mathrm{BaO} . \mathrm{Al}_{2} \mathrm{O}_{3} .7 \mathrm{H}_{2} \mathrm{O}$. The subsequent departure from the $1: 1$ line is reflected in an increase in the proportion of hydrated $\mathrm{Al}_{2} \mathrm{O}_{3}$ in the precipitate. The sudden break in the direction of high $\mathrm{BaO}$ indicates that some of the precipitated $\mathrm{BaO} \cdot \mathrm{Al}_{2} \mathrm{O}_{3} .7 \mathrm{H}_{2} \mathrm{O}$ has been hydrolyzed, with precipitation of hydrated $\mathrm{Al}_{2} \mathrm{O}_{3}$. This process continued for 2 mo or longer until no $\mathrm{BaO} . \mathrm{Al}_{2} \mathrm{O}_{3} .7 \mathrm{H}_{2} \mathrm{O}$ remained. The final vertical portion of the curve indicates that $\mathrm{Al}_{2} \mathrm{O}_{3}$ was still coming 
out of solution when the experiment was terminated.

Experiments 1-4 to 1-7 in this series were designed to determine the action of barium hydroxide solutions on monobarium aluminate. By referring to the table and the figure it may be seen that the aluminate went into solution in the 1:1 molar ratio in all cases, and that the first new phase to be precipitated was $7 \mathrm{BaO} .6 \mathrm{Al}_{2} \mathrm{O}_{3} \cdot 36 \mathrm{H}_{2} \mathrm{O}$. This compound, because of its needle-like crystalline habit, formed a voluminous precipitate with the result that the contents of the flasks acquired a thick, mushy consistency. In their subsequent behavior, these preparations differed. In experiment $1-4$, the precipitate was transformed to $\mathrm{BaO} \cdot \mathrm{Al}_{2} \mathrm{O}_{3} \cdot 7 \mathrm{H}_{2} \mathrm{O}$ within 1 day. This, in turn, showed evidence of hydrolysis after 3 mos. It may be noted parenthetically, that in this experiment, as in 1-2, more than one maximum was observed, also that some of the points in the table have been omitted from the graph for the sake of clarity. In 1-5 and 1-6, the precipitate was transformed to $\mathrm{BaO} \cdot \mathrm{Al}_{2} \mathrm{O}_{3} \cdot 4 \mathrm{H}_{2} \mathrm{O}$, without intermediate formation of the heptahydrate. There is also evidence of a shift in concentration of the solution in the direction of increasing $\mathrm{BaO}$, corresponding to the liberation of excess $\mathrm{BaO}$ as the $7: 6: 36$ hydrate was converted to the $1: 1: 4$. Experiment 1-7 followed a similar course, but with the addition of another precipitated phase, $\mathrm{Ba}(\mathrm{OH})_{2} \cdot 8 \mathrm{H}_{2} \mathrm{O}$, first noted after 10 days. The curve in this case shifts toward the left, as would be expected.

A close study of the curves in figure 1 reveals that the ascending branch does not indicate a molar ratio of exactly $1: 1$, although it is very close to that value in the case of No. 1-2. The others become progressively steeper as we go toward the high $\mathrm{BaO}$ side of the diagram, reaching the $\mathrm{BaO}: \mathrm{Al}_{2} \mathrm{O}_{3}$ ratio of $0.91: 1$ for No. 1-7. This is due to the fact that the samples for analysis were measured volumetrically, and that no correction was made for the increase in volume of the barium hydroxide solution resulting from addition of the solid aluminate. This increase was found to be of the right order of magnitude to account for the departures from the theoretical $1: 1$ slope.

The process of solution to form a supersaturated solution, followed by precipitation of a different solid phase, is characteristic of binding agents, such as portland cement and gypsum plaster. Other investigators [4] have reported that monobarium aluminate is capable of setting, and this fact was confirmed during the course of the present study. Some of the aluminate was mixed with sufficient water to make it workable, molded into a briquet, and allowed to stand in a moist closet. A moderate amount of heat was evolved shortly after molding. After $5 \mathrm{hr}$, the briquet was firm enough to be removed from the mold. After standing moist overnight and then being allowed to dry, the specimen was quite hard, but did not have enough strength to permit an actual test to be made. The material expanded about 10 percent during setting. The set product contained considerable isotropic material, probably hydrated alumina. X-ray analysis ${ }^{2}$ showed the presence of a small amount of $\mathrm{BaO} \cdot \mathrm{Al}_{2} \mathrm{O}_{3} \cdot 7 \mathrm{H}_{2} \mathrm{O}$. These observations, together with the fact that the set material is readily attacked by water, make it appear unlikely that monobarium aluminate, in itself, would have any value as a cementitious material.

\section{3. $3 \mathrm{BaO} \cdot \mathrm{Al}_{2} \mathrm{O}_{3}$}

Tribarium aluminate, $3 \mathrm{BaO} \cdot \mathrm{Al}_{2} \mathrm{O}_{3}$, reacts violently with water with the evolution of considerable heat. The course of solution and precipitation when $50 \mathrm{~g}$ of this compound was shaken with $300 \mathrm{ml}$ of water is shown in figure 2 and table 2 . It may be seen that the maximum concentration was reached in 4 min. At this time, barium hydroxide $\left(\mathrm{Ba}(\mathrm{OH})_{2}\right.$. $\left.8 \mathrm{H}_{2} \mathrm{O}\right)$ precipitated out, followed shortly by

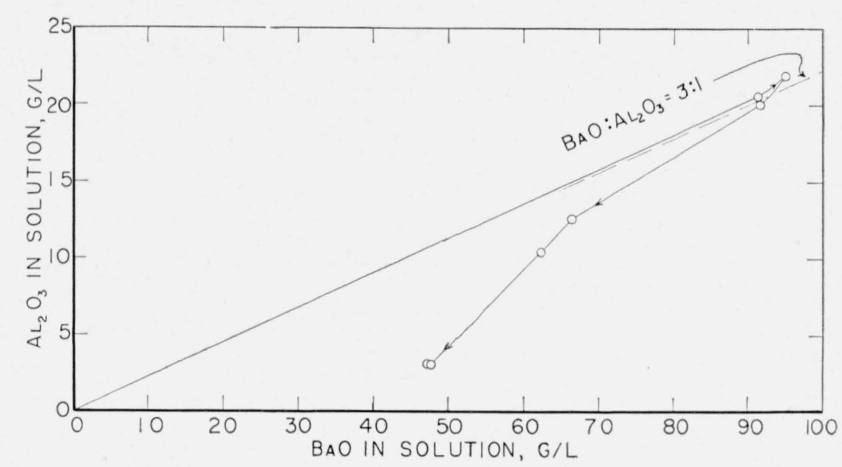

Figure 2. Solubility of $3 \mathrm{BaO} . \mathrm{Al}_{2} \mathrm{O}_{3}$ in water at $30^{\circ} \mathrm{C}$.

$7 \mathrm{BaO} .6 \mathrm{Al}_{2} \mathrm{O}_{3} .36 \mathrm{H}_{2} \mathrm{O}$. Eventually, the predominant solid phase was found to be $2 \mathrm{BaO} \cdot \mathrm{Al}_{2} \mathrm{O}_{3} \cdot 5 \mathrm{H}_{2} \mathrm{O}$ in a very finely divided form not hitherto observed. These results were confirmed by two similar experiments, in one of which the tribarium aluminate previously had been heated to the fusion point and reground. The results differed in minor details, but were in essential agreement. The fused material reacted slightly less rapidly than did the anhydrous aluminate burned at $1,300^{\circ}$.

TABLE 2. Solubility of $3 \mathrm{BaO} \cdot \mathrm{Al}_{2} \mathrm{O}_{3}$ in water at $30^{\circ} \mathrm{C}$

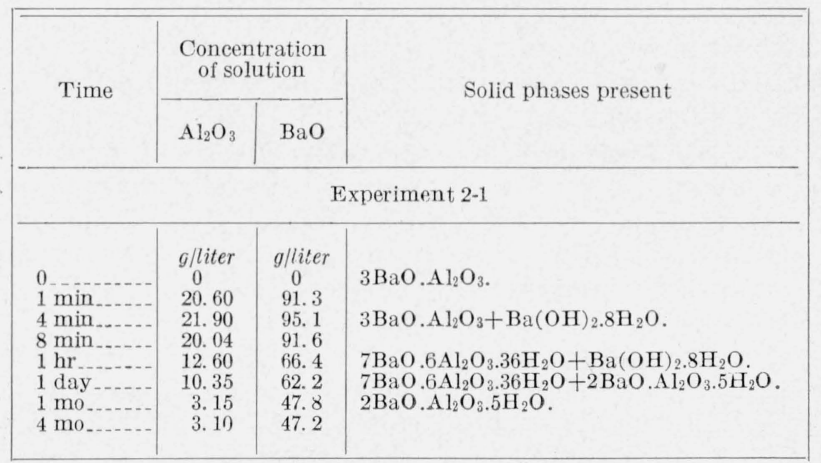

${ }^{2} \mathrm{X}$-ray diffraction patterns referred to in this paper were made by Barbara Sullivan, of the Constitution and Microstructure Section of this Bureau. 


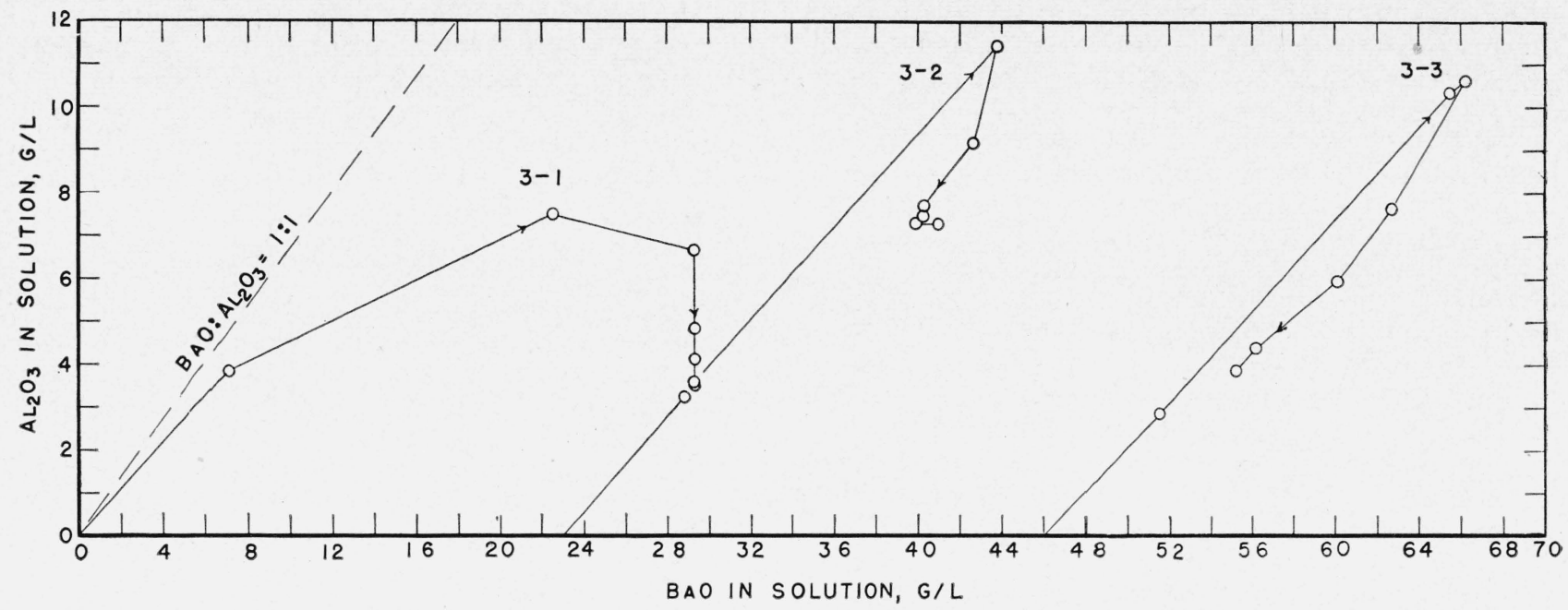

FIgure 3. Solubility of $\mathrm{BaO} \cdot \mathrm{Al}_{2} \mathrm{O}_{3} \cdot \mathrm{H}_{2} \mathrm{O}$ in water and in_barium_hydroxide solutions at $30^{\circ} \mathrm{C}$.

Inasmuch as the solution of this aluminate in water rapidly reaches a concentration at which barium hydroxide is precipitated, it appeared that little could be learned by studying its reaction with barium hydroxide solutions; hence no tests of this kind were made.

The capacity of tribarium aluminate for absorbing moisture is illustrated by the following experiment. A 5-g sample of the freshly burned aluminate was placed in a crucible and confined over water in a covered glass jar at room temperature and weighed at intervals. In 6 days it took up moisture equivalent to 13 moles of $\mathrm{H}_{2} \mathrm{O}$ per mole of $3 \mathrm{BaO} \cdot \mathrm{Al}_{2} \mathrm{O}_{3}$. From then on the increase in weight proceeded more slowly, but when the test was terminated at the end of 5 mo, the total water that had been taken up was equivalent to 43 moles of $\mathrm{H}_{2} \mathrm{O}$ per mole of $3 \mathrm{BaO}$.$\mathrm{Al}_{2} \mathrm{O}_{3}$. This is considerably more than would be required to hydrolyze the compound completely to $\mathrm{Ba}(\mathrm{OH})_{2} \cdot 8 \mathrm{H}_{2} \mathrm{O}$ and $\mathrm{Al}_{2} \mathrm{O}_{3} \cdot 3 \mathrm{H}_{2} \mathrm{O}$.

\section{4. $\mathrm{BaO} \cdot \mathrm{Al}_{2} \mathrm{O}_{3} \cdot \mathrm{H}_{2} \mathrm{O}$}

A series of three tests was made with $\mathrm{BaO} \cdot \mathrm{Al}_{2} \mathrm{O}_{3}$.$\mathrm{H}_{2} \mathrm{O}$, using pure water and half-saturated and saturated solutions of barium hydroxide. The results are given in table 3 and plotted in figure 3 . Ten grams of the crystalline hydrate, ground to pass a No. 100 sieve, was added to $200 \mathrm{ml}$ of solution. The rate of solution is seen to be relatively slow. After 5 days, the material in No. 3-1 had been converted to hydrated alumina, and the others to $7 \mathrm{BaO} .6 \mathrm{Al}_{2} \mathrm{O}_{3} .36 \mathrm{H}_{2} \mathrm{O}$. Further phase changes occurred on longer standing, as indicated in the table, and it may be assumed that if the mixtures had been kept still longer their behavior would have been essentially similar to that described below for solutions of comparable concentrations.
TABle 3. Solubility of $\mathrm{BaO} \cdot \mathrm{Al}_{2} \mathrm{O}_{3} \cdot \mathrm{H}_{2} \mathrm{O}$ in water and barium hydroxide solutions at $30^{\circ} \mathrm{C}$.

\begin{tabular}{|c|c|c|c|}
\hline \multirow{2}{*}{ Time } & \multicolumn{2}{|c|}{$\begin{array}{c}\text { Concentration of } \\
\text { solution }\end{array}$} & \multirow{2}{*}{ Solid phases present } \\
\hline & $\mathrm{Al}_{2} \mathrm{O}_{3}$ & $\mathrm{BaO}$ & \\
\hline \multicolumn{4}{|c|}{ Experiment 3-1 } \\
\hline 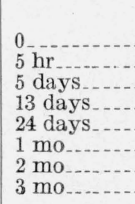 & $\begin{array}{c}\text { g/liter } \\
0 \\
3.85 \\
7.50 \\
6.67 \\
4.85 \\
4.13 \\
3.60 \\
3.45\end{array}$ & $\begin{array}{c}\text { g/liter } \\
0 \\
7.1 \\
22.5 \\
29.3 \\
29.3 \\
29.3 \\
29.3 \\
29.3\end{array}$ & $\begin{array}{l}\mathrm{BaO} \cdot \mathrm{Al}_{2} \mathrm{O}_{3} \cdot \mathrm{H}_{2} \mathrm{O} \\
\mathrm{BaO} . \mathrm{Al}_{2} \mathrm{O}_{3} \cdot \mathrm{H}_{2} \mathrm{O}+\text { hyd. } \mathrm{Al}_{2} \mathrm{O}_{3} . \\
\mathrm{Hydrated} \mathrm{Al}_{2} \mathrm{O}_{3} . \\
\text { Do. } \\
\text { Do. } \\
\text { Do. } \\
\text { Do. } \\
\text { Do. }\end{array}$ \\
\hline \multicolumn{4}{|c|}{ Experiment 3-2 } \\
\hline 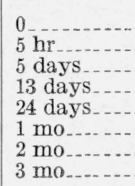 & $\begin{array}{r}0 \\
3.27 \\
11.45 \\
9.20 \\
7.75 \\
7.48 \\
7.30 \\
7.30\end{array}$ & $\begin{array}{l}(23) \\
28.8 \\
43.8 \\
42.6 \\
40.3 \\
40.3 \\
39.9 \\
41.0\end{array}$ & $\begin{array}{l}\mathrm{BaO} . \mathrm{Al}_{2} \mathrm{O}_{3} \cdot \mathrm{H}_{2} \mathrm{O} . \\
7 \mathrm{BaO} .6 \mathrm{Al}_{2} \mathrm{O}_{3} \cdot 36 \mathrm{H}_{2} \mathrm{O} . \\
\mathrm{BaO} . \mathrm{Al}_{2} \mathrm{O}_{3} \cdot 7 \mathrm{H}_{2} \mathrm{O} \text {. } \\
\text { Do. } \\
\text { DaO. } \mathrm{Al}_{2} \mathrm{O}_{3} .7 \mathrm{H}_{2} \mathrm{O}+\mathrm{BaO} . \mathrm{Al}_{2} \mathrm{O}_{3} \cdot 4 \mathrm{H}_{2} \mathrm{O} . \\
\text { Do. } \\
\text { Do. }\end{array}$ \\
\hline \multicolumn{4}{|c|}{ Experiment 3-3 } \\
\hline 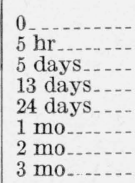 & $\begin{array}{r}{ }^{0} \\
2.85 \\
10.33 \\
10.63 \\
7.65 \\
6.01 \\
4.40 \\
3.85\end{array}$ & $\begin{array}{l}(46) \\
51.6 \\
65.5 \\
6.2 \\
62.7 \\
60.1 \\
56.2 \\
55.2\end{array}$ & $\begin{array}{l}\mathrm{BaO} . \mathrm{Al}_{2} \mathrm{O}_{3} \cdot \mathrm{H}_{2} \mathrm{O} . \\
7 \mathrm{BaO} .6 \mathrm{Al}_{2} \mathrm{O}_{3} \cdot 36 \mathrm{H}_{2} \mathrm{O} \\
7 \mathrm{BaO} .6 \mathrm{Al}_{2} \mathrm{O}_{3} .36 \mathrm{H}_{2} \mathrm{O}+\mathrm{BaO} . \mathrm{Al}_{2} \mathrm{O}_{3} \cdot 4 \mathrm{H}_{2} \mathrm{O} . \\
\mathrm{BaO} . \mathrm{Al}_{2} \mathrm{O}_{3} \cdot 4 \mathrm{H}_{2} \mathrm{O} . \\
\text { Do. } \\
\text { Do } \\
\mathrm{BaO} . \mathrm{Al}_{2} \mathrm{O}_{3} .4 \mathrm{H}_{2} \mathrm{O}+\text { hyd. } \mathrm{Al}_{2} \mathrm{O}_{3} .\end{array}$ \\
\hline
\end{tabular}

\section{5. $\mathrm{BaO} \cdot \mathrm{Al}_{2} \mathrm{O}_{3} \cdot 2 \mathrm{H}_{2} \mathrm{O}$}

A series of three experiments parallel to those described in the previous section was made with the dihydrate. The results are shown in table 4 and figure 4. Again we find that the rate of solution 


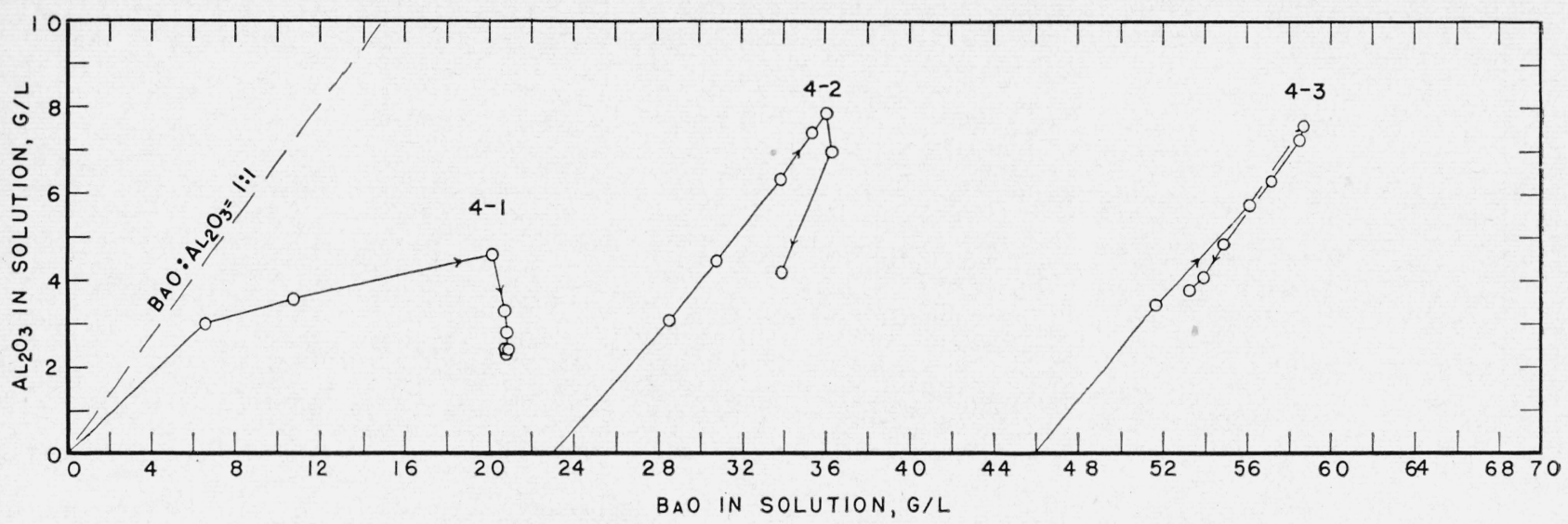

Figure 4. Solubility of $\mathrm{BaO} \cdot \mathrm{Al}_{2} \mathrm{O}_{3} \cdot 2 \mathrm{H}_{2} \mathrm{O}$ in water and in barium hydroxide solutions at $30^{\circ} \mathrm{C}$.

was relatively slow, and that the sample mixed with pure water eventually precipitated hydrated alumina. Sample 4-2, however, went into solution slowly, and no new phase was observed until after 2 mo had elapsed. Then the tetrahydrate appeared, and gradually increased at the expense of the dihydrate. Sample No. 4-3 dissolved somewhat more rapidly, and the original material had all disappeared within 1 mo, with precipitation of the tetrahydrate. A small amount of hydrated alumina was observed at the later ages in experiments $4-2$ and $4-3$.

TABLE 4. Solubility of $\mathrm{BaO} \cdot \mathrm{Al}_{2} \mathrm{O}_{3} \cdot 2 \mathrm{H}_{2} \mathrm{O}$ in water and in barium hydroxide solutions at $30^{\circ} \mathrm{C}$

\begin{tabular}{|c|c|c|c|}
\hline \multirow{2}{*}{ Time } & \multicolumn{2}{|c|}{$\begin{array}{l}\text { Concentration } \\
\text { of solution }\end{array}$} & \multirow{2}{*}{ Solid phases present } \\
\hline & $\mathrm{Al}_{2} \mathrm{O}_{3}$ & $\mathrm{BaO}$ & \\
\hline \multicolumn{4}{|c|}{ Experiment 4-1 } \\
\hline $\begin{array}{l}0 \\
5 \text { hr days } \\
13 \text { days..... } \\
24 \text { days } \\
1 \text { mo } \\
2 \text { mo } \\
3 \text { mo } \\
4 \text { mo }\end{array}$ & $\begin{array}{c}\text { g/liter } \\
0 \\
3.00 \\
3.55 \\
4.58 \\
3.25 \\
2.75 \\
2.40 \\
2.40 \\
2.28\end{array}$ & $\begin{array}{c}\text { g/liter } \\
0 \\
6.6 \\
10.8 \\
20.1 \\
20.7 \\
20.9 \\
20.7 \\
20.9 \\
20.8\end{array}$ & $\begin{array}{l}\mathrm{BaO} . \mathrm{Al}_{2} \mathrm{O}_{3} \cdot 2 \mathrm{H}_{2} \mathrm{O} . \\
\text { Do. } \\
\text { Do } \\
\mathrm{BaO} . \mathrm{Al}_{2} \mathrm{O}_{3} \cdot 2 \mathrm{H}_{2} \mathrm{O}+\text { hyd. } \mathrm{Al}_{2} \mathrm{O}_{3} . \\
\mathrm{Hydrated} \mathrm{Al}_{2} \mathrm{O}_{3} \text {. } \\
\text { Do. } \\
\text { Do. } \\
\text { Do. } \\
\text { Do. }\end{array}$ \\
\hline \multicolumn{4}{|c|}{ Experiment 4-2 } \\
\hline $\begin{array}{l}0 \mathrm{hr} \\
5 \text { days } \\
13 \text { days } . . . \\
24 \text { days } \\
1 \mathrm{mo} \\
2 \mathrm{mo} \\
3 \mathrm{mo} \\
4 \mathrm{mo}\end{array}$ & $\begin{array}{l}0 \\
3.05 \\
4.45 \\
6.30 \\
7.40 \\
7.75 \\
7.85 \\
7.00 \\
4.18\end{array}$ & $\begin{array}{l}(23) \\
28.5 \\
30.8 \\
33.8 \\
35.3 \\
35.9 \\
36.0 \\
36.3 \\
33.9\end{array}$ & $\begin{array}{l}\mathrm{BaO} . \mathrm{Al}_{2} \mathrm{O}_{3} \cdot 2 \mathrm{H}_{2} \mathrm{O} . \\
\text { Do. } \\
\text { Do. } \\
\text { Do. } \\
\text { Do. } \\
\text { Do. } \\
\mathrm{BaO} . \mathrm{Al}_{2} \mathrm{O}_{3} \cdot 2 \mathrm{H}_{2} \mathrm{O}+\mathrm{BaO} \cdot \mathrm{Al}_{2} \mathrm{O}_{3} \cdot 4 \mathrm{H}_{2} \mathrm{O} . \\
\text { Do. } \\
\mathrm{BaO} . \mathrm{Al}_{2} \mathrm{O}_{3} .4 \mathrm{H}_{2} \mathrm{O}+\text { hyd. } \mathrm{Al}_{2} \mathrm{O}_{3} .\end{array}$ \\
\hline \multicolumn{4}{|c|}{ Experiment 4-3 } \\
\hline $\begin{array}{l}0 \\
5 \mathrm{hr} \text { days } \\
13 \text { days...... } \\
24 \text { days } \\
1 \mathrm{mo} \\
2 \mathrm{mo} \\
3 \mathrm{mo} \\
4 \mathrm{mo}\end{array}$ & $\begin{array}{l}0 \\
3.43 \\
5.73 \\
7.58 \\
7.25 \\
6.32 \\
4.85 \\
4.07 \\
3.78\end{array}$ & $\begin{array}{l}(46) \\
51.7 \\
56.1 \\
58.7 \\
58.4 \\
57.1 \\
54.9 \\
53.9 \\
53.2\end{array}$ & 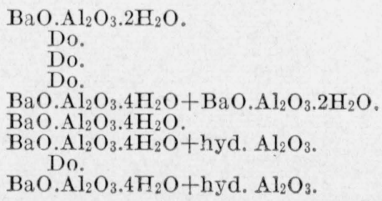 \\
\hline
\end{tabular}

\section{6. $\mathrm{BaO} \cdot \mathrm{Al}_{2} \mathrm{O}_{3} \cdot 4 \mathrm{H}_{2} \mathrm{O}$}

Preliminary experiments showed that $\mathrm{BaO} . \mathrm{Al}_{2} \mathrm{O}_{3} .4 \mathrm{H}_{2} \mathrm{O}$, unlike the compounds previously discussed, exists as a stable or metastable phase in the system $\mathrm{BaO}-\mathrm{Al}_{2} \mathrm{O}_{3}-\mathrm{H}_{2} \mathrm{O}$ at room temperature. A larger number of mixtures was therefore made, in order to ascertain the location of the solubility curve. The results obtained with this hydrate are given in table 5 and plotted in figure 5 . The rate of solution of this hydrate was relatively slow. The sample in contact with distilled water showed evidence of hydrolysis at 1 day, and hydrated alumina was observed after 2 days. After about a month, all of the $\mathrm{BaO}$ was in solution. Precipitation of hydrated alumina continued, accompanied by a drop in concentration of alumina in solution.

TABLE 5. Solubility of $\mathrm{BaO} \cdot \mathrm{Al}_{2} \mathrm{O}_{3} \cdot 4 \mathrm{H}_{2} \mathrm{O}$ in water and in barium hydroxide solutions at $30^{\circ} \mathrm{C}$

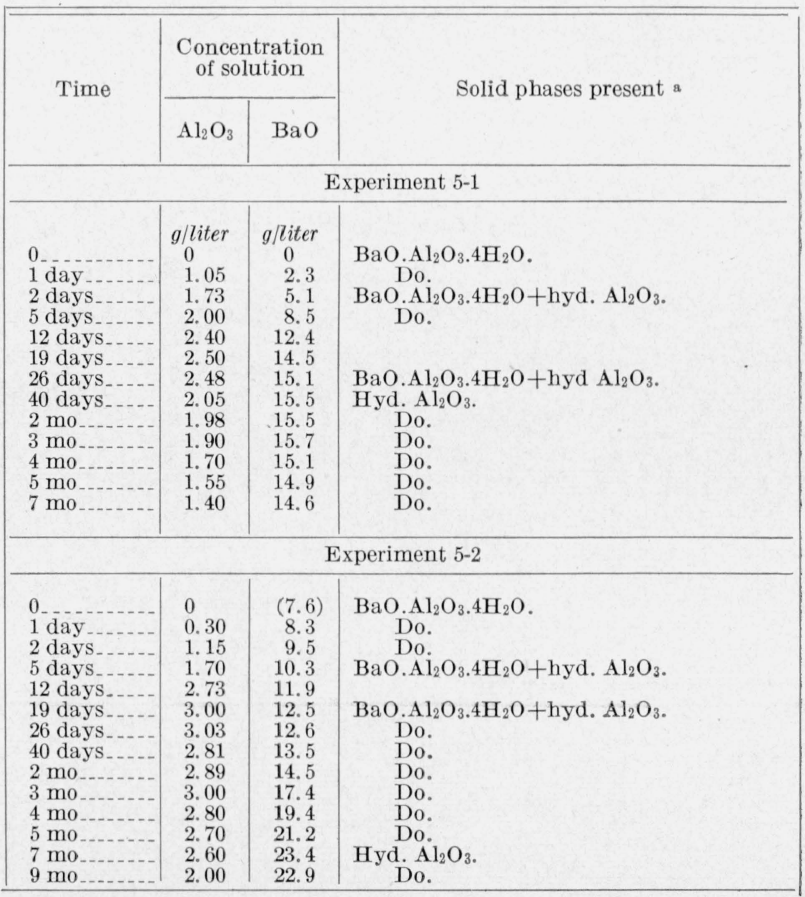




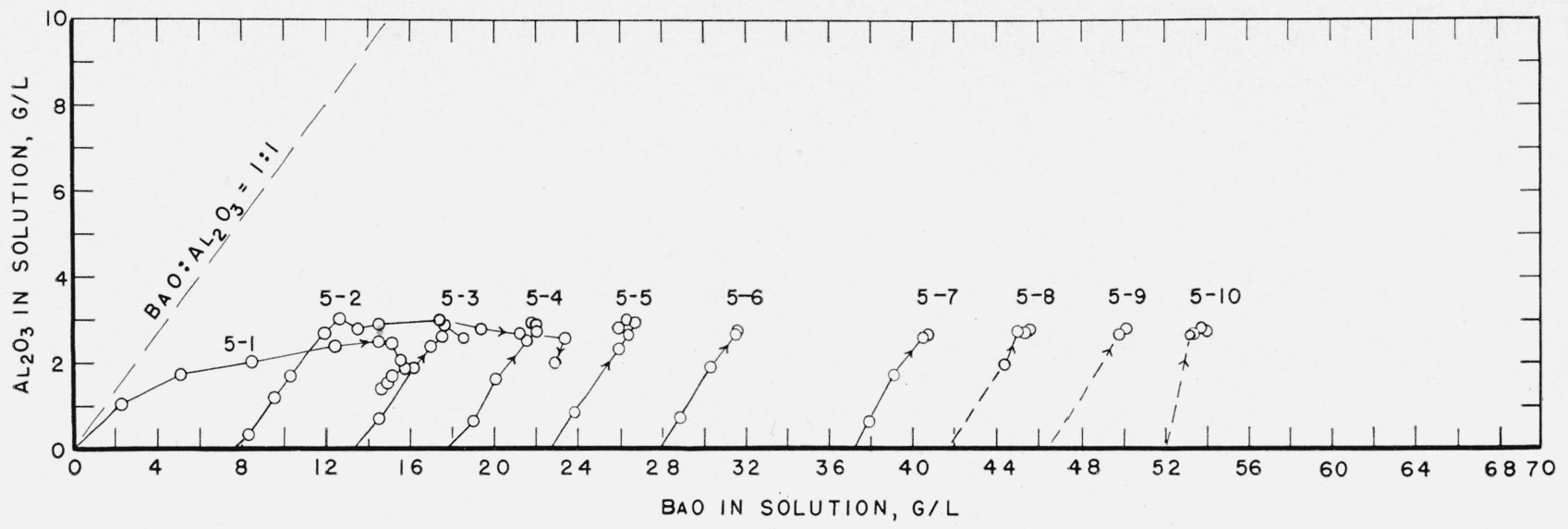

FIGURE 5. Solubility of $\mathrm{BaO} \cdot \mathrm{Al}_{2} \mathrm{O}_{3} \cdot 4 \mathrm{H}_{2} \mathrm{O}$ in water and in barium hydroxide solutions at $30^{\circ} \mathrm{C}$.

TABLE 5. Solubility of $\mathrm{BaO}_{2} \mathrm{Al}_{2} \mathrm{O}_{3} \cdot 4 \mathrm{H}_{2} \mathrm{O}$ in water and in barium hydroxide solutions at $30^{\circ} \mathrm{C}$-Continued

\begin{tabular}{|c|c|c|c|}
\hline \multirow{2}{*}{ Time } & \multicolumn{2}{|c|}{$\begin{array}{l}\text { Concentration } \\
\text { of solution }\end{array}$} & \multirow{2}{*}{ Solid phases present a } \\
\hline & $\mathrm{Al}_{2} \mathrm{O}_{3}$ & $\mathrm{BaO}$ & \\
\hline \multicolumn{4}{|c|}{ Experiment 5-3 } \\
\hline $\begin{array}{l}0 \\
1 \text { day } \\
6 \text { days } \\
15 \text { days } \\
1 \mathrm{mo} \\
2 \mathrm{mo} \\
3 \mathrm{mo} \\
4 \mathrm{mo} \\
5 \mathrm{mo} \\
8 \mathrm{mo} \\
14 \mathrm{mo}\end{array}$ & $\begin{array}{l}\text { g, } 7 \text { iter } \\
0 \\
0.67 \\
1.75 \\
2.40 \\
2.60 \\
2.85 \\
2.87 \\
2.85 \\
2.75 \\
2.90 \\
2.51\end{array}$ & $\begin{array}{l}\text { g/liter } \\
(13.3) \\
14.5 \\
15.9 \\
17.0 \\
17.5 \\
17.6 \\
17.5 \\
17.6 \\
17.7 \\
17.9 \\
18.5\end{array}$ & $\begin{array}{l}\mathrm{BaO} . \mathrm{Al}_{2} \mathrm{O}_{3} \cdot 4 \mathrm{H}_{2} \mathrm{O} . \\
\text { Do. } \\
\text { Do. } \\
\text { Do. } \\
\text { Do. } \\
\mathrm{BaO} \text {. } \mathrm{Al}_{2} \mathrm{O}_{3} .4 \mathrm{H}_{2} \mathrm{O}+\text { hyd. } \mathrm{Al}_{2} \mathrm{O}_{3} . \\
\text { Do. } \\
\text { Do. } \\
\text { Do. } \\
\text { Do. } \\
\text { Hyd. } \mathrm{Al}_{2} \mathrm{O}_{3} .\end{array}$ \\
\hline \multicolumn{4}{|c|}{ Experiment 5-4 } \\
\hline $\begin{array}{l}0 \\
6 \text { day days } \\
15 \text { days } \\
1 \mathrm{mo} \\
2 \mathrm{mo} \\
3 \mathrm{mo} \\
4 \mathrm{mo} \\
5 \mathrm{mo} \\
8 \mathrm{mo} \\
14 \mathrm{mo}\end{array}$ & $\begin{array}{l}0 \\
0.64 \\
1.65 \\
2.50 \\
2.75 \\
2.80 \\
2.82 \\
2.82 \\
2.75 \\
2.85 \\
2.85\end{array}$ & $\begin{array}{l}(17.7) \\
19.0 \\
20.1 \\
21.6 \\
22.0 \\
22.0 \\
22.1 \\
22.0 \\
22.0 \\
21.8 \\
22.0\end{array}$ & $\begin{array}{l}\mathrm{BaO} . \mathrm{Al}_{2} \mathrm{O}_{3} \cdot 4 \mathrm{H}_{2} \mathrm{O} . \\
\text { Do. } \\
\text { Do. } \\
\text { Do. } \\
\text { Do. } \\
\mathrm{BaO} \text {. } \mathrm{Al}_{2} \mathrm{O}_{3} .4 \mathrm{H}_{2} \mathrm{O} \text { +hyd. } \mathrm{Al}_{2} \mathrm{O}_{3} . \\
\text { Do. } \\
\text { Do. } \\
\text { Do. } \\
\mathrm{BaO} . \mathrm{Al}_{2} \mathrm{O}_{3} .4 \mathrm{H}_{2} \mathrm{O} \text { +hyd. } \mathrm{Al}_{2} \mathrm{O}_{3} .\end{array}$ \\
\hline \multicolumn{4}{|c|}{ Experiment 5-5 } \\
\hline $\begin{array}{l}0 \\
1 \text { day } \\
2 \text { days } \\
12 \text { days } \\
19 \text { days } \\
26 \text { days } \\
33 \text { days } \\
40 \text { days } \\
2 \text { mo } \\
3 \mathrm{mo} \\
4 \mathrm{mo} \\
6 \mathrm{mo} \\
7 \mathrm{mo}\end{array}$ & $\begin{array}{l}0 \\
0.85 \\
2.00 \\
2.35 \\
2.65 \\
2.77 \\
2.90 \\
2.95 \\
3.00 \\
2.80 \\
2.90 \\
2.83 \\
2.85\end{array}$ & $\begin{array}{l}(22.7) \\
23.8 \\
25.9 \\
26.4 \\
26.5 \\
26.5 \\
26.7 \\
26.3 \\
26.6 \\
26.4 \\
25.8 \\
25.9\end{array}$ & $\begin{array}{l}\mathrm{BaO} . \mathrm{Al}_{2} \mathrm{O}_{3} \cdot 4 \mathrm{H}_{2} \mathrm{O} . \\
\text { Do. } \\
\text { Do. } \\
\text { Do. } \\
\text { Do. } \\
\mathrm{BaO} \text {. } \mathrm{Al}_{2} \mathrm{O}_{3} .4 \mathrm{H}_{2} \mathrm{O}+\text { hyd. } \mathrm{Al}_{2} \mathrm{O}_{3} . \\
\text { Do. } \\
\text { Do. } \\
\text { Do. } \\
\text { Do. } \\
\text { Do. } \\
\mathrm{BaO} . \mathrm{Al}_{2} \mathrm{O}_{3} \cdot 4 \mathrm{H}_{2} \mathrm{O} \text { +hyd. } \mathrm{Al}_{2} \mathrm{O}_{3} . \\
\text { Do. }\end{array}$ \\
\hline \multicolumn{4}{|r|}{ Experiment 5-6 } \\
\hline $\begin{array}{l}0 \\
1 \text { day } \\
6 \text { days } \\
15 \text { days } \\
1 \text { mo } \\
2 \text { mo } \\
3 \text { mo }\end{array}$ & $\begin{array}{l}0 \\
0.73 \\
1.92 \\
2.70 \\
2.75 \\
2.75 \\
2.77\end{array}$ & $\begin{array}{l}(27.9) \\
28.8 \\
30.3 \\
31.5 \\
31.6 \\
31.6 \\
31.6\end{array}$ & $\begin{array}{l}\mathrm{BaO} . \mathrm{Al}_{2} \mathrm{O}_{3} .4 \mathrm{H}_{2} \mathrm{O} \\
\text { Do. } \\
\text { Do. } \\
\text { Do. } \\
\text { Do. } \\
\mathrm{BaO} \text {. } \mathrm{Al}_{2} \mathrm{O}_{3} .4 \mathrm{H}_{2} \mathrm{O}+\text { hyd. } \mathrm{Al}_{2} \mathrm{O}_{3} . \\
\text { Do. }\end{array}$ \\
\hline
\end{tabular}

TABLE 5. Solubility of $\mathrm{BaO} \cdot \mathrm{Al}_{2} \mathrm{O}_{3} \cdot 4 \mathrm{H}_{2} \mathrm{O}$ in water and in barium hydroxide solutions at $30^{\circ} \mathrm{C}$-Continued

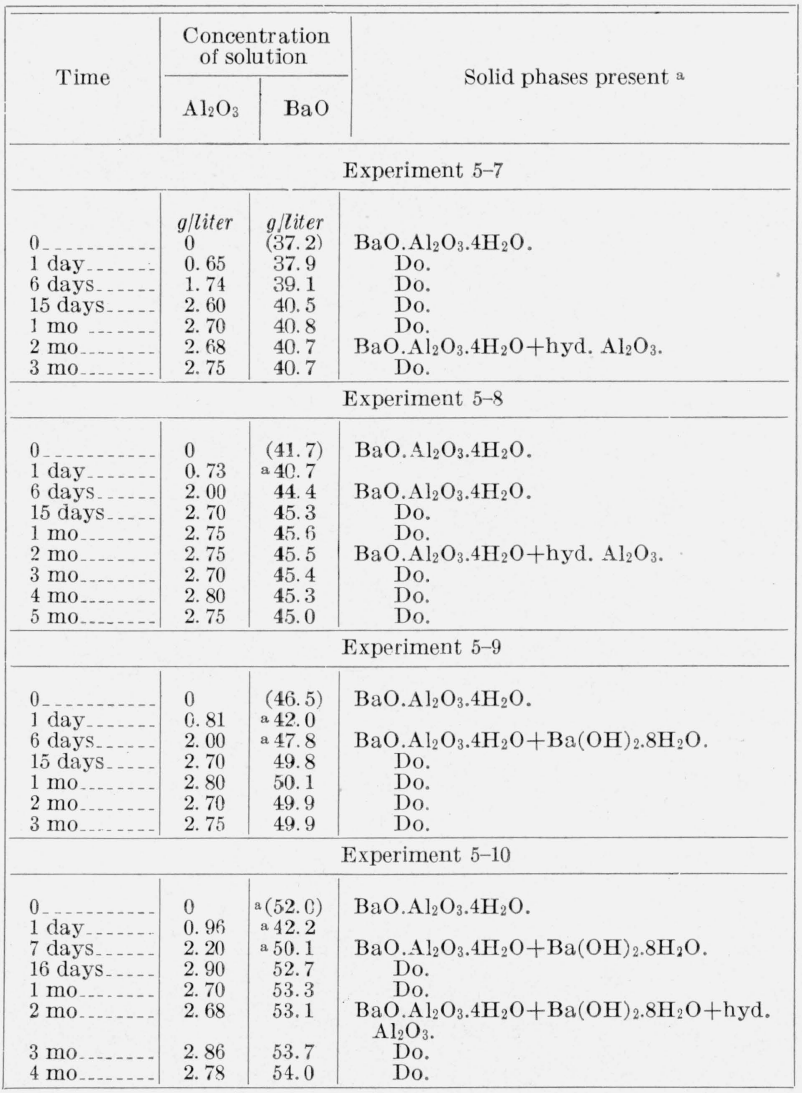

a Prepared when room temperature was below $30^{\circ}$, resulting in some precipitation of $\mathrm{Ba}(\mathrm{OH})_{2} .8 \mathrm{H}_{2} \mathrm{O}$ which redissolved very slowly. These points are not plotted in figure 5 .

In test No. 5-2, the material appeared to dissolve congruently at first, but hydrated alumina was observed after 5 days. After about a month, maximum concentration of $\mathrm{Al}_{2} \mathrm{O}_{3}$ in solution was attained. Thereafter, $\mathrm{BaO}$ continued to dissolve, leaving a residue of hydrated alumina. In many cases the original form of the crystals was maintained, but the gradual disappearance of birefringence and the 
loss of transparency gave evidence of the decomposition. After 7 mo none of the original crystalline material was observed.

All of the other samples went into solution in a molar ratio of $1: 1 \quad\left(\mathrm{BaO}: \mathrm{Al}_{2} \mathrm{O}_{3}\right)$, attaining an apparently stable condition of equilibrium. Nevertheless, hydrated alumina appeared eventually in all the flasks, indicating progressive hydrolysis. As would be expected, this reaction occurred more rapidly in the less basic solutions, but it was apparent even in those in contact with solid barium hydroxide. This will be discussed further in section III, 13.

\section{7. $\mathrm{BaO} \cdot \mathrm{Al}_{2} \mathrm{O}_{3} \cdot 7 \mathrm{H}_{2} \mathrm{O}$}

Although less stable than the tetrahydrate, the heptahydrate lasts long enough to permit a determination of its metastable solubility, and numerous tests were made for this purpose. The results obtained from some of these are given in table 6 and figure 6. In water (No. 6-1) this compound hy-

TABLE 6. Solubility of $\mathrm{BaO} \cdot \mathrm{Al}_{2} \mathrm{O}_{3} \cdot 7 \mathrm{H}_{2} \mathrm{O}$ in water and in barium hydroxide solutions at $30^{\circ} \mathrm{C}$

\begin{tabular}{|c|c|c|c|}
\hline \multirow{2}{*}{ Time } & \multicolumn{2}{|c|}{$\begin{array}{l}\text { Concentration } \\
\text { of solution }\end{array}$} & \multirow{2}{*}{ Solid phases present } \\
\hline & $\mathrm{Al}_{2} \mathrm{O}_{3}$ & $\mathrm{BaO}$ & \\
\hline \multicolumn{4}{|c|}{ Experiment 6-1 } \\
\hline $\begin{array}{l}0 \\
30 \mathrm{~min} \\
2 \mathrm{hr} \\
17 \mathrm{hr} \\
2 \text { days... } \\
5 \text { days } \\
13 \text { days } \\
2 \mathrm{mo} \\
3 \mathrm{mo} \\
6 \mathrm{mo}\end{array}$ & $\begin{array}{c}\text { g/liter } \\
0 \\
1.82 \\
2.80 \\
2.60 \\
3.30 \\
2.31 \\
1.90 \\
1.63 \\
1.45 \\
1.30\end{array}$ & $\begin{array}{l}\text { g/liter } \\
0 \\
2.74 \\
4.14 \\
6.37 \\
17.2 \\
17.3 \\
17.1 \\
17.2 \\
16.3 \\
15.7\end{array}$ & $\begin{array}{l}\mathrm{BaO} . \mathrm{Al}_{2} \mathrm{O}_{3} .7 \mathrm{H}_{2} \mathrm{O} . \\
\text { Do. } \\
\text { Do. } \\
\mathrm{BaO} . \mathrm{Al}_{2} \mathrm{O}_{3} .7 \mathrm{H}_{2} \mathrm{O}+\text { hyd. } \mathrm{Al}_{2} \mathrm{O}_{3} . \\
\mathrm{Hyd} . \mathrm{Al}_{2} \mathrm{O}_{3} . \\
\text { Do. } \\
\text { Do. } \\
\text { Do. } \\
\text { Do. } \\
\text { Do. }\end{array}$ \\
\hline \multicolumn{4}{|c|}{ Experiment 6-2 } \\
\hline 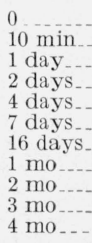 & $\begin{array}{l}0 \\
4.20 \\
6.60 \\
7.10 \\
7.46 \\
7.42 \\
7.00 \\
3.60 \\
2.85 \\
2.55 \\
2.45\end{array}$ & $\begin{array}{r}9.7 \\
15.4 \\
19.1 \\
19.5 \\
19.8 \\
20.2 \\
27.3 \\
27.6 \\
27.8 \\
27.4 \\
27.8\end{array}$ & $\begin{array}{l}\mathrm{BaO} . \mathrm{Al}_{2} \mathrm{O}_{3} .7 \mathrm{H}_{2} \mathrm{O} . \\
\text { Do. } \\
\text { Do. } \\
\text { Do. } \\
\text { Do. } \\
\text { Hyd. } \mathrm{Al}_{2} \mathrm{O}_{3} . \\
\text { Do. } \\
\text { Do. } \\
\text { Do. } \\
\text { Do. }\end{array}$ \\
\hline
\end{tabular}

TABLE 6. Solubitity of $\mathrm{BaO} \cdot \mathrm{Al}_{2} \mathrm{O}_{3} \cdot 7 \mathrm{H}_{2} \mathrm{O}$ in water and in barium hydroxide solutions at $30^{\circ} \mathrm{C}$-Continued

\begin{tabular}{|c|c|c|c|}
\hline \multirow{2}{*}{ Time } & \multicolumn{2}{|c|}{$\begin{array}{c}\text { Concentration } \\
\text { of solution }\end{array}$} & \multirow{2}{*}{ Solid phases present } \\
\hline & $\mathrm{Al}_{2} \mathrm{O}_{3}$ & $\mathrm{BaO}$ & \\
\hline \multicolumn{4}{|c|}{ Experiment 6-3 } \\
\hline $\begin{array}{l}0 \\
10 \mathrm{~min} \\
1 \mathrm{hr} \\
1 \mathrm{day} \\
4 \text { days... } \\
13 \text { days. } \\
1 \mathrm{mo} \\
2 \mathrm{mo} \\
3 \mathrm{mo} \\
4 \mathrm{mo}\end{array}$ & $\begin{array}{l}\text { g|liter } \\
0 \\
5.15 \\
5.75 \\
6.80 \\
7.00 \\
7.15 \\
7.16 \\
7.05 \\
3.70 \\
3.27\end{array}$ & $\begin{array}{l}g \mid \text { liter } \\
18.5 \\
25.4 \\
26.1 \\
27.5 \\
27.4 \\
28.3 \\
27.8 \\
29.6 \\
33.0 \\
33.0\end{array}$ & $\begin{array}{l}\mathrm{BaO} . \mathrm{Al}_{2} \mathrm{O}_{3} \cdot 7 \mathrm{H}_{2} \mathrm{O} . \\
\text { Do. } \\
\text { Do. } \\
\text { Do. } \\
\text { Do. } \\
\text { BaO. } \mathrm{Al}_{2} \mathrm{O}_{3} \cdot 7 \mathrm{H}_{2} \mathrm{O}+\text { hyd. } \mathrm{Al}_{2} \mathrm{O}_{3} . \\
\text { Hyd. } \mathrm{Al}_{2} \mathrm{O}_{3} . \\
\text { Do. }\end{array}$ \\
\hline \multicolumn{4}{|c|}{ Experiment 6-4 } \\
\hline $\begin{array}{l}15 \text { min } \\
1 \text { day } \\
2 \text { days... } \\
6 \text { days.. } \\
15 \text { days. } \\
2 \text { mo... } \\
3 \text { mo... }\end{array}$ & $\begin{array}{l}0 \\
2.70 \\
4.35 \\
6.65 \\
6.70 \\
7.45 \\
7.28 \\
7.25\end{array}$ & $\begin{array}{l}25.3 \\
28.3 \\
30.2 \\
33.6 \\
33.5 \\
34.5 \\
34.5 \\
34.3\end{array}$ & $\begin{array}{l}\text { BaO. } \mathrm{Al}_{2} \mathrm{O}_{3} .7 \mathrm{H}_{2} \mathrm{O}+\text { hyd. } \mathrm{Al}_{2} \mathrm{O}_{3} . \\
\text { Do. } \\
\mathrm{BaO} \mathrm{Al}_{2} \mathrm{O}_{3} .7 \mathrm{H}_{2} \mathrm{O}+\text { hyd. } \mathrm{Al}_{2} \mathrm{O}_{3}+\mathrm{BaO} . \\
\mathrm{Al}_{2} \mathrm{O}_{3} .4 \mathrm{H}_{2} \mathrm{O} .\end{array}$ \\
\hline \multicolumn{4}{|c|}{ Experiment 6-5 } \\
\hline $\begin{array}{l}0 . \\
10 \mathrm{~min} \\
1 \mathrm{hr} \\
1 \mathrm{day} \\
6 \text { days... } \\
15 \text { days. } \\
1 \mathrm{mo} \\
3 \mathrm{mo}\end{array}$ & $\begin{array}{l}0 \\
5.64 \\
6.42 \\
7.45 \\
7.55 \\
7.35 \\
7.70 \\
7.20\end{array}$ & $\begin{array}{l}32.3 \\
39.2 \\
40.9 \\
41.6 \\
41.3 \\
41.2 \\
41.5 \\
41.6\end{array}$ & $\begin{array}{l}\mathrm{BaO} . \mathrm{Al}_{2} \mathrm{O}_{3} .7 \mathrm{H}_{2} \mathrm{O} . \\
\text { Do. } \\
\text { Do. } \\
\text { Do. } \\
\text { Do.. } \\
\mathrm{BaO} \cdot \mathrm{Al}_{2} \mathrm{O}_{3} .7 \mathrm{H}_{2} \mathrm{O} . \\
\mathrm{BaO} . \mathrm{Al}_{2} \mathrm{O}_{3} .7 \mathrm{H}_{2} \mathrm{O}+\mathrm{BaO} . \mathrm{Al}_{2} \mathrm{O}_{3} .4 \mathrm{H}_{2} \mathrm{O} .\end{array}$ \\
\hline \multicolumn{4}{|c|}{ Experiment 6-6 } \\
\hline $\begin{array}{l}0 \\
5 \text { days } \\
1 \mathrm{mo} \\
2 \mathrm{mo} \\
3 \mathrm{mo} \\
4 \mathrm{mo} \\
5 \mathrm{mo} \\
6 \mathrm{mo}\end{array}$ & $\begin{array}{l}0 \\
6.70 \\
7.10 \\
7.30 \\
7.14 \\
7.00 \\
7.00 \\
7.08\end{array}$ & $\begin{array}{l}(40.0) \\
49.7 \\
50.1 \\
50.5 \\
50.5 \\
50.2 \\
50.3 \\
50.2\end{array}$ & $\begin{array}{l}\mathrm{BaO} O \mathrm{Al}_{2} \mathrm{O}_{3} .7 \mathrm{H}_{2} \mathrm{O} . \\
\text { Do. } \\
\text { Do. } \\
\text { Do. } \\
\text { Do. } \\
\text { Do. } \\
\text { Do. } \\
\text { Do. }\end{array}$ \\
\hline \multicolumn{4}{|c|}{ Experiment 6-7 } \\
\hline $\begin{array}{l}0 \\
1 \mathrm{hr} . \\
1 \mathrm{day} . \\
6 \text { days... } \\
15 \text { days. } \\
1 \mathrm{mo} \\
4 \mathrm{mo}\end{array}$ & $\begin{array}{l}0 \\
4.35 \\
4.86 \\
7.22 \\
7.75 \\
7.60 \\
7.60\end{array}$ & $\begin{array}{l}47.1 \\
52.0 \\
52.7 \\
54.1 \\
55.1 \\
55.4 \\
54.5\end{array}$ & $\begin{array}{l}\mathrm{BaO} . \mathrm{Al}_{2} \mathrm{O}_{3} .7 \mathrm{H}_{2} \mathrm{O} . \\
\text { Do. } \\
\text { Do. } \\
\text { Do. } \\
\text { Do. } \\
\text { Do. } \\
\text { Do. }\end{array}$ \\
\hline
\end{tabular}

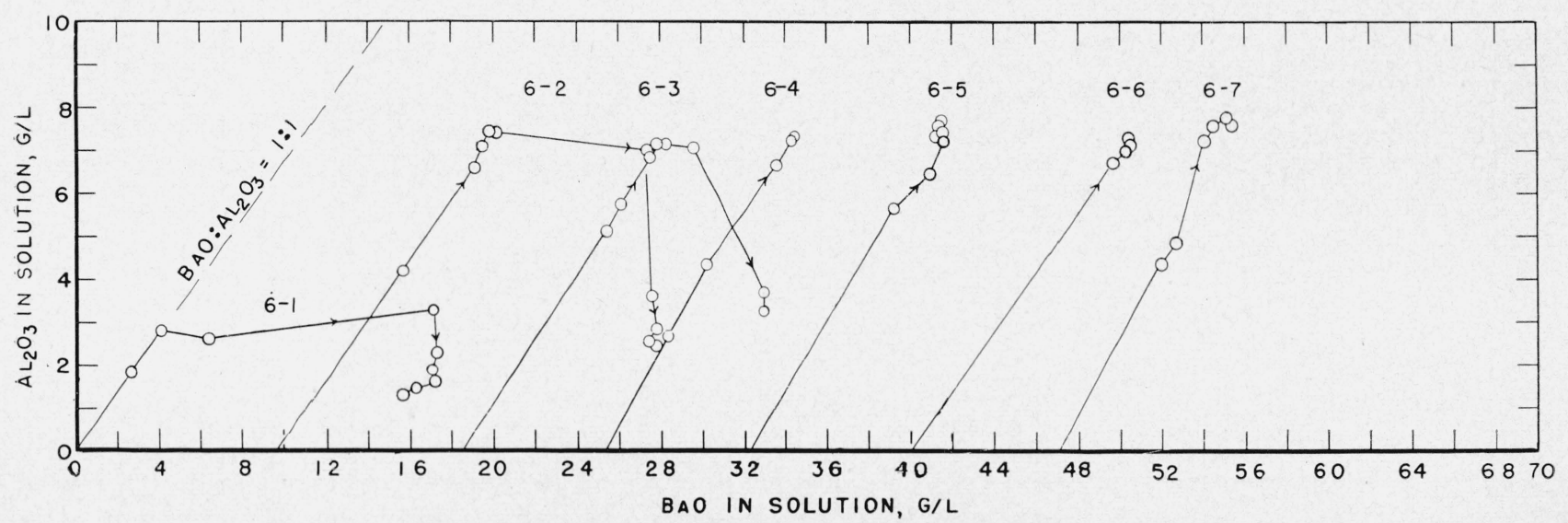

Figure 6. Solubility of $\mathrm{BaO} \cdot \mathrm{Al}_{2} \mathrm{O}_{3} \cdot 7 \mathrm{H}_{2} \mathrm{O}$ in water and in barium hydroxide solutions at $30^{\circ} \mathrm{C}$. 
drolyzed rapidly, with precipitation of hydrated alumina. The approximately horizontal portion of the curve indicates that solution and precipitation proceeded simultaneously until the hydrate was exhausted.

In experiment $6-2$, the least basic of the barium hydroxide solutions used, hydrolysis was not apparent until after 7 days. The concentration, meanwhile, had remained approximately constant for several days, and this concentration was taken as the metastable solubility of $\mathrm{BaO} \cdot \mathrm{Al}_{2} \mathrm{O}_{3} .7 \mathrm{H}_{2} \mathrm{O}$ at this point. The subsequent behavior of the mixture was similar to that of 6-1. Experiment 6-3 followed the pattern of 6-2, except that the hydrolysis in this case did not proceed rapidly until after 2 mo. All the mixtures in the more basic region reached a condition of equilibrium that persisted until the experiment was terminated. It will be shown below, however, that this equilibrium is actually metastable, and that $\mathrm{BaO} \cdot \mathrm{Al}_{2} \mathrm{O}_{3} .7 \mathrm{H}_{2} \mathrm{O}$ is not the final reaction product.

\section{8. $7 \mathrm{BaO} .6 \mathrm{Al}_{2} \mathrm{O}_{3} \cdot 36 \mathrm{H}_{2} \mathrm{O}$}

The results of experiments with $7 \mathrm{BaO} \cdot 6 \mathrm{Al}_{2} \mathrm{O}_{3} .36 \mathrm{H}_{2} \mathrm{O}$ are given in table 7 and figure 7 . In general, this compound behaves much as does the heptahydrate, but it is more soluble and considerably less stable. In experiment 7-1, the hydrate dissolved almost completely in water within $10 \mathrm{~min}$, with simultaneous precipitation of amorphous hydrated alumina. The latter process contimued at a diminishing rate, and equilibrium was not reached even after several months. In 7-2 the hydrolysis was much slower, and some of the original hydrate was still present after 4 days. At 8 days, however, the remainder of the hydrate was found to have been transformed into $\mathrm{BaO} . \mathrm{Al}_{2} \mathrm{O}_{3} .7 \mathrm{H}_{2} \mathrm{O}$. The latter phase soon disappeared, and for some time the precipitation of alumina continued, as evidenced by the vertical portion of the curve. At 3 mo., $\mathrm{BaO} \cdot \mathrm{Al}_{2} \mathrm{O}_{3} \cdot 4 \mathrm{H}_{2} \mathrm{O}$ was first observed as a solid phase, and there is an accompanying break in the curve toward the left.
TABLE 7. Solubility of $7 \mathrm{BaO} \cdot 6 \mathrm{Al}_{2} \mathrm{O}_{3} \cdot 36 \mathrm{H}_{2} \mathrm{O}$ in water and in barium hydroxide solutions at $30^{\circ} \mathrm{C}$

\begin{tabular}{|c|c|c|c|}
\hline \multirow{2}{*}{ Time } & \multicolumn{2}{|c|}{$\begin{array}{l}\text { Concentration of } \\
\text { solution }\end{array}$} & \multirow{2}{*}{ Solid phases present } \\
\hline & $\mathrm{Al}_{2} \mathrm{O}_{3}$ & $\mathrm{BaO}$ & \\
\hline \multicolumn{4}{|c|}{ Experiment 7-1 } \\
\hline $\begin{array}{l}0 \\
10 \mathrm{~min} \\
2 \mathrm{hr} \\
1 \mathrm{day} \\
2 \text { days } \\
9 \text { days } \\
19 \text { days } \\
1 \text { mo } \\
2 \mathrm{mo} \\
3 \mathrm{mo} \\
4 \mathrm{mo} \\
5 \mathrm{mo} \\
7 \mathrm{mo}\end{array}$ & $\begin{array}{c}\text { g/liter } \\
0 \\
8.80 \\
9.30 \\
9.30 \\
6.60 \\
3.80 \\
3.00 \\
2.75 \\
2.43 \\
2.35 \\
2.20 \\
1.95 \\
1.95\end{array}$ & $\begin{array}{c}\text { g/liter } \\
0 \\
16.6 \\
17.5 \\
19.4 \\
19.4 \\
19.4 \\
19.1 \\
19.0 \\
18.6 \\
18.6 \\
18.8 \\
18.5 \\
18.4\end{array}$ & $\begin{array}{l}7 \mathrm{BaO} .6 \mathrm{Al}_{2} \mathrm{O}_{3} .36 \mathrm{H}_{2} \mathrm{O} . \\
7 \mathrm{BaO} .6 \mathrm{Al}_{2} \mathrm{O}_{3} .36 \mathrm{H}_{2} \mathrm{O}+\text { hyd. } \mathrm{Al}_{2} \mathrm{O}_{3} . \\
\mathrm{Hyd} \text {. } \mathrm{Al}_{2} \mathrm{O}_{3} . \\
\text { Do. } \\
\text { Do. } \\
\text { Do. } \\
\text { Do. } \\
\text { Do. } \\
\text { Do. } \\
\text { Do. } \\
\text { Do. } \\
\text { Do. } \\
\text { Do. }\end{array}$ \\
\hline \multicolumn{4}{|c|}{ Experiment 7-2 } \\
\hline $\begin{array}{l}0 \\
13 \mathrm{~min} \\
2 \mathrm{hr} \\
1 \mathrm{day} \\
4 \text { days } \\
8 \text { days.-. } \\
18 \text { days } \\
1 \mathrm{mo} \\
2 \mathrm{mo} \\
3 \mathrm{mo} \\
4 \mathrm{mo} \\
5 \mathrm{mo} \\
7 \mathrm{mo}\end{array}$ & $\begin{array}{r}0 \\
9.40 \\
\text { 11. } 40 \\
11.80 \\
\text { 10. } 86 \\
9.00 \\
6.60 \\
5.40 \\
4.35 \\
\text { 3. } 75 \\
3.55 \\
3.30 \\
\text { 3. } \\
\end{array}$ & $\begin{array}{r}7.8 \\
24.7 \\
29.5 \\
29.6 \\
29.8 \\
29.4 \\
29.5 \\
28.5 \\
28.0 \\
29.1 \\
29.0 \\
28.8\end{array}$ & $\begin{array}{l}7 \mathrm{BaO} .6 \mathrm{Al}_{2} \mathrm{O}_{3} \cdot 36 \mathrm{H}_{2} \mathrm{O} . \\
7 \mathrm{BaO} .6 \mathrm{Al}_{2} \mathrm{O}_{3} .36 \mathrm{H}_{2} \mathrm{O}+\text { hyd. } \mathrm{Al}_{2} \mathrm{O}_{3} . \\
\text { Do. } \\
\text { Do. } \\
\mathrm{BaO} \text {. } \mathrm{Al}_{2} \mathrm{O}_{3} .7 \mathrm{H}_{2} \mathrm{O}+\text { hyd. } \mathrm{Al}_{2} \mathrm{O}_{3} . \\
\mathrm{Hyd} . \mathrm{Al}_{2} \mathrm{O}_{3} . \\
\text { Do. } \\
\text { Do. } \\
\mathrm{Hyd} \mathrm{Al}_{2} \mathrm{O}_{3}+\mathrm{BaO} . \mathrm{Al}_{2} \mathrm{O}_{3} .4 \mathrm{H}_{2} \mathrm{O} \text { (trace). } \\
\text { Do. } \\
\text { Do. } \\
\text { Hyd. } \mathrm{Al}_{2} \mathrm{O}_{3} .\end{array}$ \\
\hline \multicolumn{4}{|c|}{ Experiment 7-3 } \\
\hline $\begin{array}{l}0 \\
10 \mathrm{~min} \\
1 \mathrm{hr} \\
1 \text { day } \\
2 \text { days } \\
5 \text { days.... } \\
14 \text { days } \\
1 \text { mo } \\
2 \text { mo } \\
3 \text { mo } \\
4 \text { mo } \\
6 \text { mo }\end{array}$ & $\begin{aligned} & 0 \\
& 6 . 34 \\
& 8.90 \\
& 12 . 10 \\
& 12 . 20 \\
& 12 . 00 \\
& 7.93 \\
& 7.05 \\
& 6.75 \\
& \text { 5. } 00 \\
& 4.30 \\
& \text { 3. } 95\end{aligned}$ & $\begin{array}{l}15.2 \\
25.7 \\
29.2 \\
34.3 \\
35.2 \\
36.7 \\
34.4 \\
36.6 \\
41.8 \\
42.3 \\
42.1 \\
41.7\end{array}$ & $\begin{array}{l}7 \mathrm{BaO} .6 \mathrm{Al}_{2} \mathrm{O}_{3} \cdot 36 \mathrm{H}_{2} \mathrm{O} . \\
\text { Do. } \\
\text { Do. } \\
\text { Do. } \\
\text { Do. } \\
\text { BaO. } \mathrm{Al}_{2} \mathrm{O}_{3} .7 \mathrm{H}_{2} \mathrm{O}+\text { hyd. } \mathrm{Al}_{2} \mathrm{O}_{3} . \\
\text { Do. } \\
\mathrm{Hyd} \text {. } \mathrm{Al}_{2} \mathrm{O}_{3}+\mathrm{BaO} . \mathrm{Al}_{2} \mathrm{O}_{3} .4 \mathrm{H}_{2} \mathrm{O} \text { (trace). } \\
\text { Do. } \\
\text { Do. } \\
\text { Do. }\end{array}$ \\
\hline
\end{tabular}

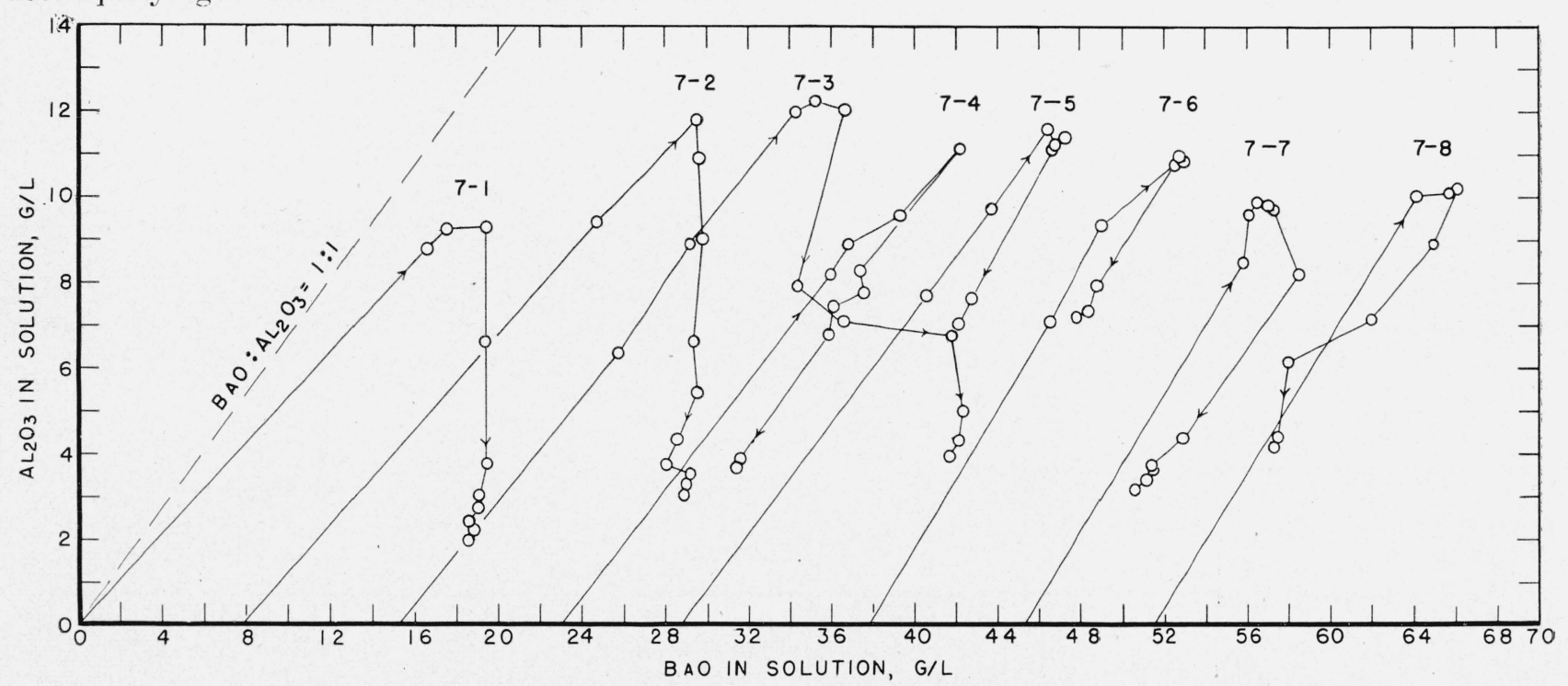

Figure 7. Solubility of $7 \mathrm{BaO} \cdot 6 \mathrm{Al}_{2} \mathrm{O}_{3} \cdot 36 \mathrm{H}_{2} \mathrm{O}$ in water and in barium hydroxide solutions at $30^{\circ} \mathrm{C}$. 
TABLE 7. Solubility of $7 \mathrm{BaO} \cdot 6 \mathrm{Al}_{2} \mathrm{O}_{3} \cdot 36 \mathrm{H}_{2} \mathrm{O}$ in water and in barium hydroxide solutions at $30^{\circ} \mathrm{C}$-Continued

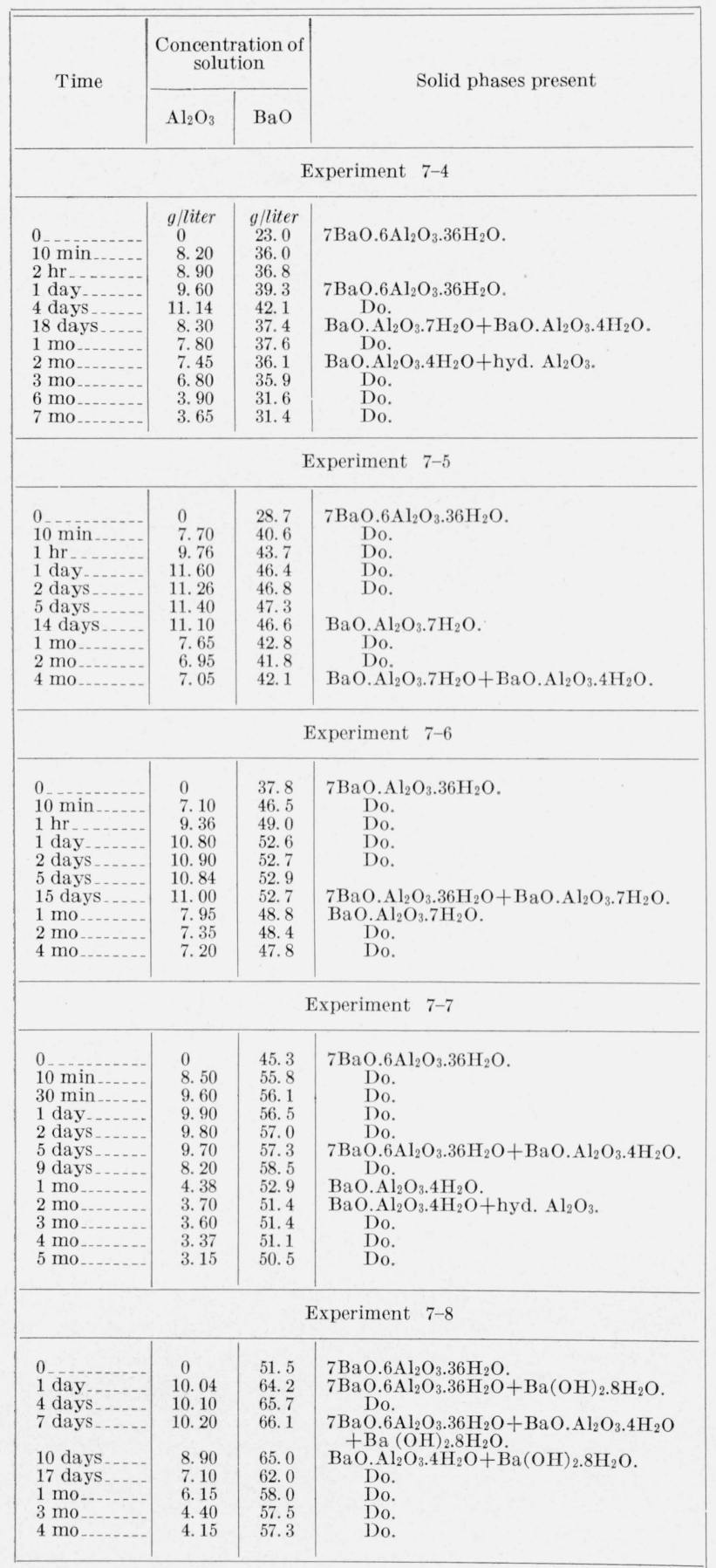

Mixtures in the more basic region reached a maximum concentration that persisted long enough (5 to 15 days) to permit the plotting of an approximate metastable solubility curve in this range. The data and curve for experiment 7-3 show that it resembled $7-2$, except that in the more basic solution the intermediate phase, $\mathrm{BaO} \cdot \mathrm{Al}_{2} \mathrm{O}_{3} \cdot 7 \mathrm{H}_{2} \mathrm{O}$, persisted longer. Experiment 7-3 shows another peculiarity in that the heptahydrate formed was subsequently hydrolyzed, with a corresponding increase in basicity of the solution. Experiments 7-4, 7-5, and 7-6, in solutions progressively more basic, are characterized by greater stability of the intermediate phase, $\mathrm{BaO} \cdot \mathrm{Al}_{2} \mathrm{O}_{3} \cdot 7 \mathrm{H}_{2} \mathrm{O}$, and by a decrease in the amount of hydrated alumina precipitated. In 7-7 and 7-8, the heptahydrate no longer appears as an intermediate phase, the original hydrate being transformed directly into the tetrahydrate. In $7-8, \mathrm{Ba}(\mathrm{OH})_{2} \cdot 8 \mathrm{H}_{2} \mathrm{O}$ also appears as a solid phase. The reverse kink in the curve for this mixture reflects a temporary failure of the temperature control, which permitted the temperature to fall about $1 \mathrm{deg}$, resulting in precipitation of more barium hydroxide.

\section{9. $2 \mathrm{BaO} \cdot \mathrm{Al}_{2} \mathrm{O}_{3} \cdot 5 \mathrm{H}_{2} \mathrm{O}$}

Results of solubility experiments with $2 \mathrm{BaO} \cdot \mathrm{Al}_{2} \mathrm{O}_{3} .5 \mathrm{H}_{2} \mathrm{O}$ are given in table 8 and figure 8 . This hydrate dissolved in water without any precipitation at first, so that the molar ratio of $\mathrm{BaO}$ to $\mathrm{Al}_{2} \mathrm{O}_{3}$ in solution remained approximately $2: 1$. Precipitation of hydrated alumina was first observed after 26 days. The remaining crystalline material thereupon went into solution as alumina continued to separate out.

TABLE 8. Solubility of $2 \mathrm{BaO} \cdot \mathrm{Al}_{2} \mathrm{O}_{3} \cdot 5 \mathrm{H}_{2} \mathrm{O}$ in water and in barium hydroxide solutions at $30^{\circ} \mathrm{C}$-Continued

\begin{tabular}{|c|c|c|c|}
\hline \multirow{2}{*}{ Time } & \multicolumn{2}{|c|}{$\begin{array}{l}\text { Concentration } \\
\text { of solution }\end{array}$} & \multirow{2}{*}{ Solid phases present } \\
\hline & $\mathrm{Al}_{2} \mathrm{O}_{3}$ & $\mathrm{BaO}$ & \\
\hline \multicolumn{4}{|c|}{ Experiment 8-1 } \\
\hline $\begin{array}{l}0 \\
1 \text { day } \\
5 \text { days } \\
12 \text { days... } \\
19 \text { days. } \\
26 \text { days. } \\
33 \text { days. } \\
40 \text { days. } \\
2 \text { mo } \\
3 \text { mo } \\
4 \text { mo } \\
6 \text { mo } \\
10 \\
\text { mo }\end{array}$ & $\begin{array}{l}\text { g/liter } \\
0 \\
3.42 \\
5.05 \\
5.50 \\
6.10 \\
6.15 \\
5.60 \\
4.55 \\
3.40 \\
2.70 \\
2.55 \\
2.15 \\
1.87\end{array}$ & $\begin{array}{c}\text { g/liter } \\
0 \\
10.4 \\
16.8 \\
18.4 \\
19.7 \\
20.8 \\
20.9 \\
21.1 \\
20.6 \\
20.6 \\
20.3 \\
19.9\end{array}$ & $\begin{array}{l}2 \mathrm{BaO} . \mathrm{Al}_{2} \mathrm{O}_{3} \cdot 5 \mathrm{H}_{2} \mathrm{O} . \\
2 \mathrm{BaO} . \mathrm{Al}_{2} \mathrm{O}_{3} \cdot 5 \mathrm{H}_{2} \mathrm{O} . \\
\quad \text { Do. } \\
\text { Do. } \\
2 \mathrm{BaO} \cdot \mathrm{Al}_{2} \mathrm{O}_{3} .5 \mathrm{H}_{2} \mathrm{O}+\text { hyd. } \mathrm{Al}_{2} \mathrm{O}_{3} . \\
\mathrm{Hyd} . \mathrm{Al}_{2} \mathrm{O}_{3} . \\
\mathrm{Hyd} . \mathrm{Al}_{2} \mathrm{O}_{3} . \\
\text { Do. } \\
\text { Do. } \\
\text { Do. } \\
\text { Do. }\end{array}$ \\
\hline \multicolumn{4}{|c|}{ Experiment 8-2 } \\
\hline 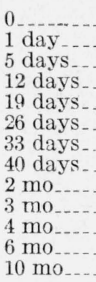 & $\begin{array}{l}0 \\
2.18 \\
3.55 \\
3.98 \\
4.60 \\
4.90 \\
5.15 \\
5.48 \\
5.52 \\
5.35 \\
5.35 \\
4.69 \\
3.05\end{array}$ & $\begin{array}{l}(8.5) \\
14.9 \\
20.3 \\
21.9 \\
22.6 \\
23.1 \\
24.3 \\
24.1 \\
24.2 \\
24.2 \\
23.6 \\
23.5\end{array}$ & $\begin{array}{l}2 \mathrm{BaO} . \mathrm{Al}_{2} \mathrm{O}_{3} .5 \mathrm{H}_{2} \mathrm{O} . \\
2 \mathrm{BaO} . \mathrm{Al}_{2} \mathrm{O}_{3} \cdot 5 \mathrm{H}_{2} \mathrm{O} . \\
\text { Do. } \\
\text { Do. } \\
\text { 2BaO. } \mathrm{Al}_{2} \mathrm{O}_{3} .5 \mathrm{H}_{2} \mathrm{O}+\text { hyd. } \mathrm{Al}_{2} \mathrm{O}_{3} . \\
\text { Do. } \\
\text { 2BaO. } \mathrm{Al}_{2} \mathrm{O}_{3} .5 \mathrm{H}_{2} \mathrm{O}+\text { hyd. } \mathrm{Al}_{2} \mathrm{O}_{3} . \\
\mathrm{Hyd} . \mathrm{Al}_{2} \mathrm{O}_{3} . \\
\text { Do. } \\
\text { Do. } \\
\text { Do. }\end{array}$ \\
\hline \multicolumn{4}{|c|}{ Experiment 8-3 } \\
\hline $\begin{array}{l}0 . \\
1 \text { day } \\
5 \text { days } . . . \\
12 \text { days } . \\
19 \text { days } \\
26 \text { days } \\
33 \text { days. } \\
40 \text { days. } \\
2 \text { no } \\
3 \text { mo } \\
4 \text { mo } \\
6 \text { mo }\end{array}$ & $\begin{array}{l}0 \\
1.85 \\
3.20 \\
4.00 \\
4.70 \\
5.00 \\
5.15 \\
5.25 \\
5.25 \\
5.12 \\
5.30 \\
5.15\end{array}$ & $\begin{array}{l}(17.0) \\
23.0 \\
29.3 \\
31.2 \\
32.0 \\
32.3 \\
32.9 \\
32.4 \\
32.8 \\
32.5 \\
32.0\end{array}$ & $\begin{array}{l}2 \mathrm{BaO} . \mathrm{Al}_{2} \mathrm{O}_{3} .5 \mathrm{H}_{2} \mathrm{O} . \\
2 \mathrm{BaO} . \mathrm{Al}_{2} \mathrm{O}_{3} .5 \mathrm{H}_{2} \mathrm{O}+\text { hyd. } \mathrm{Al}_{2} \mathrm{O}_{3} \text {. } \\
\text { Do. } \\
\text { Do. } \\
\text { Do. } \\
\text { Do. } \\
\text { 2BaO. } \mathrm{Al}_{2} \mathrm{O}_{3} .5 \mathrm{H}_{2} \mathrm{O} \text { +hyd. } \mathrm{Al}_{2} \mathrm{O}_{3} \text {. } \\
\text { Do. } \\
\text { Do. } \\
\text { Do. }\end{array}$ \\
\hline
\end{tabular}




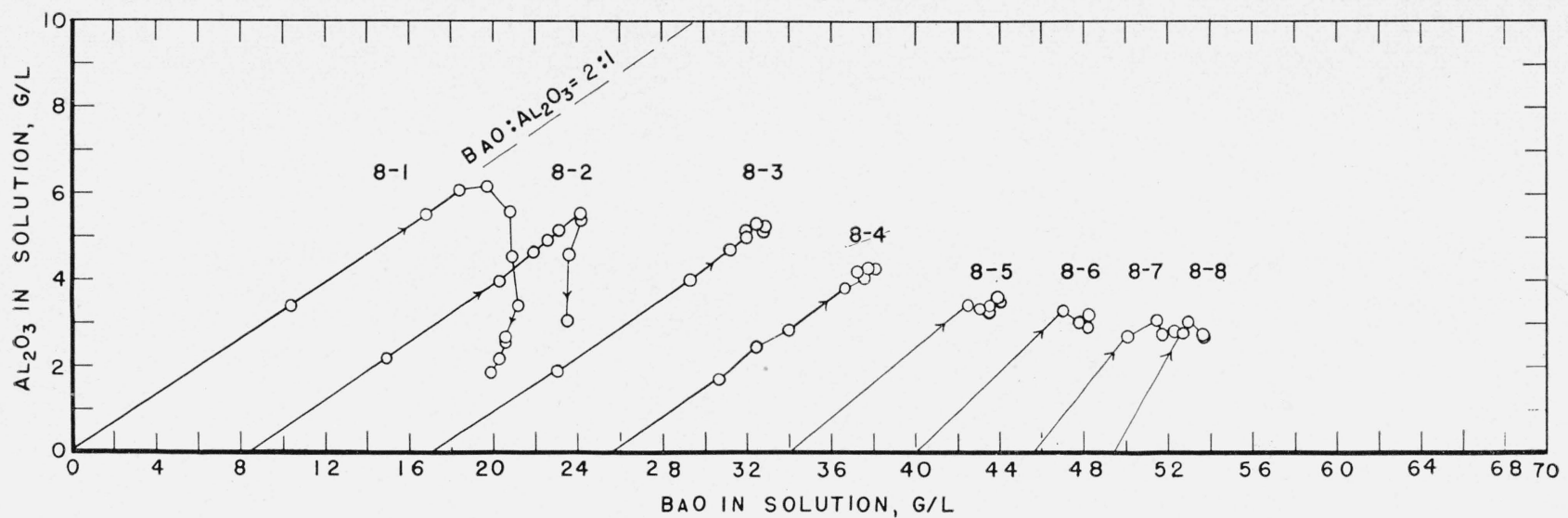

FIgURE 8. Solubility of $2 \mathrm{BaO} \cdot \mathrm{Al}_{2} \mathrm{O}_{3} .5 \mathrm{H}_{2} \mathrm{O}$ in water and in barium hydroxide solutions at $30^{\circ} \mathrm{C}$.

TABLE 8. Solubility of $2 \mathrm{BaO} . \mathrm{Al}_{2} \mathrm{O}_{3} .5 \mathrm{H}_{2} \mathrm{O}$ in water and in barium hydroxide solutions at $30^{\circ} \mathrm{C}$-Continued

\begin{tabular}{|c|c|c|c|}
\hline \multirow{2}{*}{ Time } & \multicolumn{2}{|c|}{$\begin{array}{l}\text { Concentration } \\
\text { of solution }\end{array}$} & \multirow{2}{*}{ Sclid phases present } \\
\hline & $\mathrm{Al}_{2} \mathrm{O}_{3}$ & $\mathrm{BaO}$ & \\
\hline \multicolumn{4}{|r|}{ Experiment $8-4$} \\
\hline $\begin{array}{l}0 \\
1 \text { day } \\
2 \text { days } \\
5 \text { days } \\
12 \text { days } \\
19 \text { days } \\
26 \text { days } \\
40 \text { days } \\
2 \mathrm{mo} \\
3 \mathrm{mo} \\
4 \mathrm{mo} \\
5 \mathrm{mo} \\
\end{array}$ & $\begin{array}{l}\text { g/liter } \\
0 \\
1.70 \\
2.45 \\
2.85 \\
3.80 \\
4.20 \\
4.30 \\
4.15 \\
4.25 \\
4.40 \\
4.20 \\
4.05\end{array}$ & $\begin{array}{l}\text { g/liter } \\
(25.7) \\
30.7 \\
32.5 \\
34.0 \\
36.7 \\
37.8 \\
37.8 \\
38.0 \\
38.1 \\
37.9 \\
37.3 \\
37.6\end{array}$ & $\begin{array}{l}2 \mathrm{BaO} . \mathrm{Al}_{2} \mathrm{O}_{3} .5 \mathrm{H}_{2} \mathrm{O} . \\
\text { Do. } \\
\text { 2BaO. } \mathrm{Al}_{2} \mathrm{O}_{3} .5 \mathrm{H}_{2} \mathrm{O}+\text { hyd. } \mathrm{Al}_{2} \mathrm{O}_{3} . \\
\text { Do. }\end{array}$ \\
\hline \multicolumn{4}{|r|}{ Experiment 8-5 } \\
\hline $\begin{array}{l}9 \text { days } \\
22 \text { days } \\
36 \text { days } \ldots \\
2 \text { mo } \\
3 \text { mo } \\
4 \mathrm{mo} \\
5 \mathrm{mo}\end{array}$ & $\begin{array}{l}0 \\
\text { 3. } 40 \\
\text { 3. } 40 \\
3.60 \\
\text { 3. } 25 \\
\text { 3. } 35 \\
3.35 \\
\text { 3. } 40 \\
\end{array}$ & $\begin{array}{l}(34.2) \\
42.5 \\
43.6 \\
43.9 \\
43.5 \\
43.1 \\
43.8 \\
44.0 \\
\end{array}$ & $\begin{array}{l}2 \mathrm{BaO} . \mathrm{Al}_{2} \mathrm{O}_{3} .5 \mathrm{H}_{2} \mathrm{O} . \\
2 \mathrm{BaO} . \mathrm{Al}_{2} \mathrm{O}_{3} .5 \mathrm{H}_{2} \mathrm{O}+\text {-hyd. } \mathrm{Al}_{2} \mathrm{O}_{3} . \\
\text { Do. } \\
\text { Do. } \\
\text { Do. } \\
\text { Do. } \\
\text { Do. } \\
\text { Do. }\end{array}$ \\
\hline \multicolumn{4}{|r|}{ Experiment 8-6 } \\
\hline $\begin{array}{l}0 \\
9 \text { days } \\
22 \text { days } \\
2 \mathrm{mo} \\
3 \mathrm{mo} \\
4 \mathrm{mo} \\
5 \mathrm{mo}\end{array}$ & $\begin{array}{l}0 \\
\text { 3. } 30 \\
\text { 3. } 02 \\
\text { 3. } 20 \\
2.90 \\
\text { 3. } 02 \\
2.99 \\
2.95\end{array}$ & $\begin{array}{l}(39.9) \\
47.0 \\
48.0 \\
48.2 \\
48.2 \\
47.8 \\
48.2 \\
48.1 \\
\end{array}$ & $\begin{array}{l}2 \mathrm{BaO} . \mathrm{Al}_{2} \mathrm{O}_{3} .5 \mathrm{H}_{2} \mathrm{O} . \\
2 \mathrm{BaO} . \mathrm{Al}_{2} \mathrm{O}_{3} .5 \mathrm{H}_{2} \mathrm{O}+\text { hyd. } \mathrm{Al}_{2} \mathrm{O}_{3} . \\
\text { Do. } \\
\text { Do. } \\
\text { Do. } \\
\text { Do. } \\
\text { Do. } \\
\text { Do. }\end{array}$ \\
\hline \multicolumn{4}{|r|}{ Experiment 8-7 } \\
\hline $\begin{array}{l}0 \\
92 \text { days } \\
36 \text { days } \\
2 \mathrm{mo} \\
3 \mathrm{mo} \\
4 \mathrm{mo}\end{array}$ & 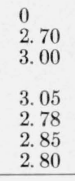 & $\begin{array}{r}45.6 \\
50.1 \\
\text { a } 4.0 \\
\\
51.5 \\
51.7 \\
52.1 \\
52.3 \\
\end{array}$ & $\begin{array}{l}2 \mathrm{BaO} \cdot \mathrm{Al}_{2} \mathrm{O}_{3} \cdot 5 \mathrm{H}_{2} \mathrm{O} \\
2 \mathrm{BaO} \cdot \mathrm{Al}_{2} \mathrm{O}_{3} \cdot 5 \mathrm{H}_{2} \mathrm{O}+\mathrm{Ba}(\mathrm{OH})_{2} \cdot 8 \mathrm{H}_{2} \mathrm{O} . \\
2 \mathrm{BaO} . \mathrm{Al}_{2} \mathrm{O}_{3} \cdot 5 \mathrm{H}_{2} \mathrm{O}+\mathrm{Ba}(\mathrm{OH})_{2} \cdot 8 \mathrm{H}_{2} \mathrm{O}+\text { hyd. } \\
\mathrm{Al}_{2} \mathrm{O}_{3} . \\
\text { Do. } \\
\text { Do. } \\
\text { Do. } \\
2 \mathrm{BaO} . \mathrm{Al}_{2} \mathrm{O}_{3} .5 \mathrm{H}_{2} \mathrm{O}+\text { hyd. } \mathrm{Al}_{2} \mathrm{O}_{3} .\end{array}$ \\
\hline \multicolumn{4}{|r|}{ Experiment 8-8 } \\
\hline $\begin{array}{l}0 \\
22 \text { days } \\
36 \text { days } \\
2 \text { mo } \\
3 \text { mo } \\
4 \text { mo }\end{array}$ & 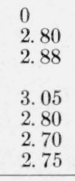 & $\begin{array}{r}(49.4) \\
52.7 \\
\text { a } 48.4 \\
\\
52.9 \\
\text { a } 50.0 \\
53.7 \\
53.7\end{array}$ & $\begin{array}{l}2 \mathrm{BaO} . \mathrm{Al}_{2} \mathrm{O}_{3} .5 \mathrm{H}_{2} \mathrm{O} . \\
2 \mathrm{BaO} . \mathrm{Al}_{2} \mathrm{O}_{3} .5 \mathrm{H}_{2} \mathrm{O}+\mathrm{Ba}(\mathrm{OH})_{2} .8 \mathrm{H}_{2} \mathrm{O}+\text { hyd. } \\
\mathrm{Al}_{2} \mathrm{O}_{3} . \\
\text { Do. } \\
\text { Do. } \\
\text { Do. } \\
\text { Do. }\end{array}$ \\
\hline
\end{tabular}

a Fluctuations in $\mathrm{BaO}$ concentration reflect temporary failure of temperature control.
In barium hydroxide solutions, the course of solution was similar, but the original hydrate appeared to be more stable as the concentration of barium hydroxide increased. Although small amounts of hydrated alumina were formed in all cases, much of the crystalline material remained even after 5 mo, except in 8-2, the least basic of these mixtures.

\section{Precipitation From Supersaturated Solutions}

In any study of phase equilibria in aqueous solutions, it is desirable to approach equilibrium from both sides, that is, from supersaturation as well as undersaturation. This is particularly true when reactions are slow and when metastable phases may be formed. In the present study, it was found that precipitation from supersaturated solution gave results that were not always reproducible and that often were difficult to interpret. This phase of the investigation, the first actually to be undertaken, yielded information vital to an understanding of the various solid phases and their formation, but it did not furnish a clear picture of the equilibrium relationships in the system. The solubility experiments described in the preceding sections proved to be essential to a clarification of these relationships.

Supersaturated solutions for the precipitation experiments were prepared as described in section II, 7. These were kept in the $30^{\circ} \mathrm{C}$ cabinet with occasional shaking, and samples of the solutions were pipetted out from time to time for analysis. Small samples of the solid phases that precipitated were also taken for microscopic examination. Out of a large number of such solutions prepared at various times, a few have been selected as typical of the group, and the results are presented in table 9 and figure 9 .

Examination of the curve for Experiment 9-1 shows that the precipitation followed a straight line, aside from slight irregularities that may be attributed to experimental errors. The last two analyses indicate a slight but definite shift toward a lower concentration of $\mathrm{BaO}$. This is probably due to crystallization of $\mathrm{Ba}(\mathrm{OH})_{2} .8 \mathrm{H}_{2} \mathrm{O}$ on the wall of the flask above the level of the liquid, a phenomenon observed in a number of the flasks after standing for 
TABLE 9. Precipitation from supersaturated barium aluminate solutions at $30^{\circ} \mathrm{C}$

\begin{tabular}{|c|c|c|c|}
\hline \multirow{2}{*}{ Time } & \multicolumn{2}{|c|}{$\begin{array}{c}\text { Concentration of } \\
\text { solution }\end{array}$} & \multirow{2}{*}{ Solid phases present } \\
\hline & $\mathrm{Al}_{2} \mathrm{O}_{3}$ & $\mathrm{BaO}$ & \\
\hline \multicolumn{4}{|c|}{ Experiment 9-1 } \\
\hline $\begin{array}{l}0 \\
1 \text { day } \\
2 \text { days } \\
5 \text { days } \\
13 \text { days } \\
20 \text { days } \ldots \\
29 \text { days } . . . \\
47 \text { days } \\
2 \text { mo } \\
3 \text { mo } \\
4 \text { mo } \\
6 \text { mo }\end{array}$ & $\begin{array}{r}\text { g/liter } \\
17.80 \\
16.38 \\
8.08 \\
5.58 \\
3.90 \\
3.50 \\
3.45 \\
3.20 \\
2.95 \\
2.65 \\
2.45 \\
2.45\end{array}$ & \begin{tabular}{l|} 
g/liter \\
27.8 \\
27.1 \\
26.1 \\
25.8 \\
25.5 \\
26.0 \\
26.1 \\
26.0 \\
25.8 \\
25.6 \\
24.8 \\
24.7
\end{tabular} & $\begin{array}{l}\text { None. } \\
\text { Hyd. } \mathrm{Al}_{2} \mathrm{O}_{3} . \\
\text { Do. } \\
\text { Do. } \\
\text { Do. } \\
\text { Do. } \\
\text { Do. } \\
\text { Do. } \\
\text { Do. } \\
\text { Do. } \\
\text { Do. } \\
\text { Do. }\end{array}$ \\
\hline \multicolumn{4}{|c|}{ Experiment 9-2 } \\
\hline $\begin{array}{l}0 \\
1 \text { day } \\
2 \text { days } \\
5 \text { days } \\
13 \text { days } \\
20 \text { days } . . . \\
29 \text { days } . . . \\
47 \text { days } . . \\
2 \text { mo } \\
4 \text { mo mo } \\
6 \text { mo }\end{array}$ & $\begin{array}{r}\text { 19. } 24 \\
18.92 \\
17.66 \\
9.12 \\
6.70 \\
5.60 \\
5.00 \\
4.40 \\
3.93 \\
3.50 \\
3.30 \\
3.10\end{array}$ & $\begin{array}{l}35.6 \\
34.9 \\
34.9 \\
32.2 \\
32.5 \\
33.6 \\
33.7 \\
33.7 \\
33.8 \\
33.4 \\
33.1 \\
32.8\end{array}$ & $\begin{array}{l}\text { None. } \\
\text { Hyd. } \mathrm{Al}_{2} \mathrm{O}_{3} \text {. } \\
\text { Do. } \\
\mathrm{Hyd} \mathrm{Al}_{2} \mathrm{O}_{3}+\mathrm{BaO} . \mathrm{Al}_{2} \mathrm{O}_{3} \cdot 7 \mathrm{H}_{2} \mathrm{O} \text {. } \\
\text { Do. } \\
\mathrm{Dyd} \text {. } \mathrm{Al}_{2} \mathrm{O}_{3} . \\
\text { Do. } \\
\text { Do. } \\
\text { Do. } \\
\text { Do. } \\
\text { Do. } \\
\text { Do. }\end{array}$ \\
\hline \multicolumn{4}{|c|}{ Experiment 9-3 } \\
\hline $\begin{array}{l}0 \\
1 \text { day } \\
2 \text { days } \\
5 \text { days } \\
13 \text { days } \ldots \ldots \\
20 \text { days } \\
47 \text { days } \\
2 \text { mo } \\
3 \text { mo } \\
4 \text { mo } \\
6 \text { mo } \\
7 \text { mo } \\
8 \text { mo }\end{array}$ & $\begin{array}{r}19.40 \\
19.34 \\
14.36 \\
10.16 \\
8.14 \\
7.70 \\
7.46 \\
7.32 \\
6.86 \\
6.80 \\
7.00 \\
7.10 \\
7.25\end{array}$ & $\begin{array}{l}43.8 \\
43.5 \\
36.6 \\
30.8 \\
28.0 \\
27.6 \\
26.9 \\
26.7 \\
25.7 \\
25.6 \\
25.4 \\
38.8 \\
42.9\end{array}$ & $\begin{array}{l}\text { None. } \\
7 \mathrm{BaOO} .6 \mathrm{Al}_{2} \mathrm{O}_{3} .36 \mathrm{H}_{2} \mathrm{O} . \\
7 \mathrm{BaO} .6 \mathrm{Al}_{2} \mathrm{O}_{3} .36 \mathrm{H}_{2} \mathrm{O}+\mathrm{BaO} . \mathrm{Al}_{2} \mathrm{O}_{3} .7 \mathrm{H}_{2} \mathrm{O} . \\
\mathrm{BaO} . \mathrm{Al}_{2} \mathrm{O}_{3} .7 \mathrm{H}_{2} \mathrm{O} \\
\mathrm{BaO} \mathrm{Al}_{2} \mathrm{O}_{3} .7 \mathrm{H}_{2} \mathrm{O}+\text { hyd. } \mathrm{Al}_{2} \mathrm{O}_{3} . \\
\text { Do. } \\
\text { Do. } \\
\text { Do. } \\
\text { Do. } \\
\text { Do. } \\
\text { Do. } \\
\text { Do. }\end{array}$ \\
\hline \multicolumn{4}{|c|}{ Experiment 9-4 } \\
\hline $\begin{array}{l}0 \\
5 \mathrm{mo} \\
7 \mathrm{mo} \\
9 \mathrm{mo} \\
12 \mathrm{mo} \\
15 \mathrm{mo} \\
18 \mathrm{mo} \\
\end{array}$ & $\begin{array}{r}14.10 \\
7.48 \\
6.60 \\
4.66 \\
4.05 \\
3.40 \\
3.20\end{array}$ & $\begin{array}{l}37.8 \\
30.7 \\
37.4 \\
37.1 \\
36.9 \\
36.8 \\
36.5\end{array}$ & $\begin{array}{l}\text { None. } \\
\mathrm{BaO} \mathrm{Al}_{2} \mathrm{O}_{3} .7 \mathrm{H}_{2} \mathrm{O} . \\
\mathrm{Hyd} \text {. } \mathrm{Al}_{2} \mathrm{O}_{3} . \\
\text { Do. } \\
\text { Do. } \\
\text { Do. } \\
\text { Do. } \\
\text { Do. }\end{array}$ \\
\hline \multicolumn{4}{|c|}{ Experiment 9-5 } \\
\hline 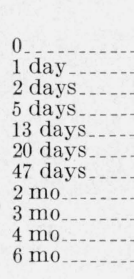 & $\begin{array}{r}\text { g/ititer } \\
20.04 \\
19.30 \\
11.90 \\
9.20 \\
7.40 \\
7.30 \\
7.10 \\
7.05 \\
7.23 \\
7.25 \\
7.12\end{array}$ & $\begin{array}{c}\text { g/liter } \\
51.5 \\
51.0 \\
40.5 \\
36.8 \\
34.6 \\
34.2 \\
33.8 \\
33.6 \\
33.6 \\
33.5 \\
32.9\end{array}$ & $\begin{array}{l}\text { None. } \\
\text { 7 } \mathrm{BaO} .6 \mathrm{Al}_{2} \mathrm{O}_{3} .36 \mathrm{H}_{2} \mathrm{O} . \\
7 \mathrm{BaO} .6 \mathrm{Al}_{2} \mathrm{O}_{3} .36 \mathrm{H}_{2} \mathrm{O}+\mathrm{BaO} . \mathrm{Al}_{2} \mathrm{O}_{3} .7 \mathrm{H}_{2} \mathrm{O} . \\
\mathrm{BaO} \text {. } \mathrm{Al}_{2} \mathrm{O}_{3} .7 \mathrm{H}_{2} \mathrm{O} . \\
\text { Do. } \\
\text { Do. } \\
\text { Do. } \\
\text { Do. } \\
\text { Do. } \\
\text { Do. } \\
\text { Do. }\end{array}$ \\
\hline \multicolumn{4}{|c|}{ Experiment 9-6 } \\
\hline $\begin{array}{l}0 \\
1 \text { day } \\
4 \text { days } \\
7 \text { days } \ldots \ldots \\
11 \text { days } \ldots . . . \\
15 \text { days } \\
2 \text { mo } \\
7 \text { mo } \\
11 \text { mo } \\
15 \text { mo } \\
18 \text { mo }\end{array}$ & $\begin{array}{r}17.65 \\
17.39 \\
13.29 \\
11.41 \\
10.78 \\
8.75 \\
7.43 \\
7.24 \\
5.18 \\
3.86 \\
3.40\end{array}$ & $\begin{array}{l}51.7 \\
51.1 \\
43.5 \\
40.2 \\
42.6 \\
39.4 \\
38.0 \\
36.6 \\
47.4 \\
45.2 \\
44.5\end{array}$ & $\begin{array}{l}\text { None. } \\
7 \mathrm{BaO} .6 \mathrm{Al}_{2} \mathrm{O}_{3} \cdot 36 \mathrm{H}_{2} \mathrm{O} . \\
\text { Do. } \\
\text { Do } \\
\mathrm{BaO} . \mathrm{Al}_{2} \mathrm{O}_{3} \cdot 7 \mathrm{H}_{2} \mathrm{O} . \\
\text { Do. } \\
\text { Do. } \\
\text { Doo. } \\
\text { Da. } \\
\text { Do. } \mathrm{Al}_{2} \mathrm{O}_{3} \cdot 4 \mathrm{H}_{2} \mathrm{O}+\text { hyd. } \mathrm{Al}_{2} \mathrm{O}_{3} . \\
\text { Do. } \\
\text { Do. }\end{array}$ \\
\hline
\end{tabular}

TABLE 9. Precipitation from supersaturated barium aluminate solutions at $30^{\circ} \mathrm{C}$-Continued

\begin{tabular}{|c|c|c|c|}
\hline \multirow{2}{*}{ Time } & \multicolumn{2}{|c|}{$\begin{array}{c}\text { Concentration of } \\
\text { solution }\end{array}$} & \multirow{2}{*}{ Solid phases present } \\
\hline & $\mathrm{Al}_{2} \mathrm{O}_{3}$ & $\mathrm{BaO}$ & \\
\hline \multicolumn{4}{|c|}{ Experiment 9-7 } \\
\hline $\begin{array}{l}0 \\
1 \text { day } \\
2 \text { days.-- } \\
5 \text { days.- } \\
9 \text { days.- } \\
15 \text { days. } \\
20 \text { days. } \\
47 \text { days. } \\
2 \text { mo }\end{array}$ & $\begin{array}{r}\text { g/liter } \\
20.20 \\
16.46 \\
13.42 \\
11.30 \\
8.47 \\
7.90 \\
7.30 \\
7.00 \\
7.00\end{array}$ & \begin{tabular}{l|l} 
g/liter & \\
59.4 & 54.2 \\
49.5 & \\
47.2 & \\
44.5 & 43.3 \\
42.4 & \\
41.8 & \\
41.4 &
\end{tabular} & $\begin{array}{l}\text { None. } \\
7 \mathrm{BaO} .6 \mathrm{Al}_{2} \mathrm{O}_{3} .36 \mathrm{H}_{2} \mathrm{O} . \\
\text { Do. } \\
7 \mathrm{BaO} .6 \mathrm{Al}_{2} \mathrm{O}_{3} .36 \mathrm{H}_{2} \mathrm{O}+\mathrm{BaO} . \mathrm{Al}_{2} \mathrm{O}_{3} \cdot 7 \mathrm{H}_{2} \mathrm{O} . \\
\mathrm{BaO} \text {. } \mathrm{Al}_{2} \mathrm{O}_{3} .7 \mathrm{H}_{2} \mathrm{O} . \\
\text { Do. } \\
\text { Do. } \\
\text { Do. } \\
\text { Do. }\end{array}$ \\
\hline \multicolumn{4}{|c|}{ Experiment 9-8 } \\
\hline $\begin{array}{l}0 . \\
1 \text { day } \\
2 \text { days.-- } \\
5 \text { days.- } \\
9 \text { days.- } \\
13 \text { days. } \\
20 \text { days. } \\
47 \text { days } \\
2 \text { mo }\end{array}$ & $\begin{array}{r}17.74 \\
17.52 \\
15.28 \\
11.22 \\
8.70 \\
7.74 \\
7.60 \\
7.30 \\
7.05\end{array}$ & \begin{tabular}{l|l}
64.3 \\
62.7 \\
59.8 \\
54.3 \\
51.7 \\
50.0 \\
49.7 \\
49.3 \\
48.5
\end{tabular} & $\begin{array}{l}\text { None. } \\
7 \mathrm{BaO} .6 \mathrm{Al}_{2} \mathrm{O}_{3} .36 \mathrm{H}_{2} \mathrm{O} . \\
\text { Do. } \\
7 \mathrm{BaO} .6 \mathrm{Al}_{2} \mathrm{O}_{3} .36 \mathrm{H}_{2} \mathrm{O}+\mathrm{BaO} . \mathrm{Al}_{2} \mathrm{O}_{3} .7 \mathrm{H}_{2} \mathrm{O} . \\
\mathrm{BaO} . \mathrm{Al}_{2} \mathrm{O}_{3} .7 \mathrm{H}_{2} \mathrm{O} . \\
\text { Do. } \\
\text { Do. } \\
\text { Do. } \\
\text { Do. }\end{array}$ \\
\hline \multicolumn{4}{|c|}{ Experiment 9-9 } \\
\hline $\begin{array}{l}0 \\
6 \text { days }\end{array}$ & 14. 16 & 59.2 & $\begin{array}{l}\text { None. } \\
\text { BaO. } \mathrm{Al}_{2} \mathrm{O}_{3} .7 \mathrm{H}_{2} \mathrm{O}+7 \mathrm{BaO} .6 \mathrm{Al}_{2} \mathrm{O}_{3} .36 \mathrm{H}_{2} \mathrm{O}\end{array}$ \\
\hline $\begin{array}{l}10 \text { days } \\
3 \text { mo } \\
7 \mathrm{mo} \\
11 \mathrm{mo} \text { mo-..- } \\
13 \mathrm{mo} \\
15 \mathrm{mo}\end{array}$ & $\begin{array}{r}\text { 11. } 44 \\
7.68 \\
\text { 4. } 00 \\
\text { 3. } 38 \\
\text { 3. } 30 \\
\text { 3. } 30\end{array}$ & $\begin{array}{l}54.9 \\
50.3 \\
44.1 \\
43.2 \\
43.2 \\
43.2\end{array}$ & $\begin{array}{l}\mathrm{BaO} . \mathrm{Al}_{2} \mathrm{O}_{3} .7 \mathrm{H}_{2} \mathrm{O} \\
\mathrm{BaO} . \mathrm{Al}_{2} \mathrm{O}_{3} .7 \mathrm{H}_{2} \mathrm{O}+\mathrm{BaO} . \mathrm{Al}_{2} \mathrm{O}_{3} \cdot 4 \mathrm{H}_{2} \mathrm{O} . \\
\mathrm{BaO} . \mathrm{Al}_{2} \mathrm{O}_{3} \cdot 4 \mathrm{H}_{2} \mathrm{O}+\text { hyd. } \mathrm{Al}_{2} \mathrm{O}_{3} . \\
\text { Do. } \\
\text { Do. } \\
\text { Do. }\end{array}$ \\
\hline \multicolumn{4}{|c|}{ Experiment 9-10 } \\
\hline $\begin{array}{l}0 \ldots \\
0 \mathrm{mo} \\
7 \mathrm{mo} \\
9 \mathrm{mo} \\
12 \mathrm{mo} \\
15 \mathrm{mo} \\
18 \mathrm{mo}\end{array}$ & $\begin{array}{r}11.10 \\
7.80 \\
6.00 \\
5.20 \\
4.32 \\
\text { 4. } 00 \\
\text { 3. } 75\end{array}$ & $\begin{array}{l}60.8 \\
55.9 \\
53.8 \\
52.5 \\
51.3 \\
50.5 \\
50.4\end{array}$ & $\begin{array}{l}\text { None. } \\
\text { BaO.Al } \mathrm{A}_{2} \mathrm{O}_{3} .7 \mathrm{H}_{2} \mathrm{O}+\mathrm{BaO} . \mathrm{Al}_{2} \mathrm{O}_{3} \cdot 4 \mathrm{H}_{2} \mathrm{O} . \\
\mathrm{BaO} \text {. } \mathrm{H}_{2} \mathrm{O}_{3} .4 \mathrm{H}_{2} \mathrm{O}+\text { hyd. } \mathrm{Al}_{2} \mathrm{O}_{3} . \\
\text { Do. } \\
\text { Do. } \\
\text { Do. } \\
\text { Do. }\end{array}$ \\
\hline \multicolumn{4}{|c|}{ Experiment 9-11 } \\
\hline $\begin{array}{l}0 \\
10 \text { days } \\
1 \text { mo } \\
2 \text { mo...- } \\
3 \text { mo }\end{array}$ & $\begin{array}{r}12.10 \\
11.75 \\
8.00 \\
6.00 \\
4.85\end{array}$ & $\begin{array}{l}68.1 \\
67.6 \\
63.2 \\
59.3 \\
58.0\end{array}$ & $\begin{array}{l}\mathrm{Ba}(\mathrm{OH})_{2} .8 \mathrm{H}_{2} \mathrm{O} . \\
\mathrm{Ba}(\mathrm{OH})_{2} .8 \mathrm{H}_{2} \mathrm{O}+\mathrm{BaO} . \mathrm{Al}_{2} \mathrm{O}_{3} \cdot 4 \mathrm{H}_{2} \mathrm{O} . \\
\mathrm{Ba}(\mathrm{OH})_{2} .8 \mathrm{H}_{2} \mathrm{O}+\mathrm{BaO} . \mathrm{Al}_{2} \mathrm{O}_{3} \cdot 4 \mathrm{H}_{2} \mathrm{O} .\end{array}$ \\
\hline
\end{tabular}

several months. Disregarding these two points, the average slope of the line indicates a molar ratio, $\mathrm{BaO}: \mathrm{Al}_{2} \mathrm{O}_{3}=0.10: 1$, in the precipitate. Analysis of the precipitate after 7 mo gave a molar ratio, $\mathrm{BaO}: \mathrm{Al}_{2} \mathrm{O}_{3}: \mathrm{H}_{2} \mathrm{O}=0.07: 1: 3.27$.

The precipitate was bulky, and under the microscope appeared as extremely fine, irregular, isotropic grains, with refractive index about 1.57 , close to the median index of gibbsite $\left(\mathrm{Al}_{2} \mathrm{O}_{3} \cdot 3 \mathrm{H}_{2} \mathrm{O}\right)$. The X-ray diffraction pattern showed the stronger lines of gibbsite, superimposed on a broad band indicative of amorphous material. It is inferred that the precipitate originally was amorphous, and that crystallization to gibbsite occurred progressively on aging. The $\mathrm{BaO}$ present may be assumed to be adsorbed.

Experiment 9-2 followed a similar course, except that a small amount of $\mathrm{BaO} \cdot \mathrm{Al}_{2} \mathrm{O}_{3} .7 \mathrm{H}_{2} \mathrm{O}$ appeared as an intermediate product and persisted for several 


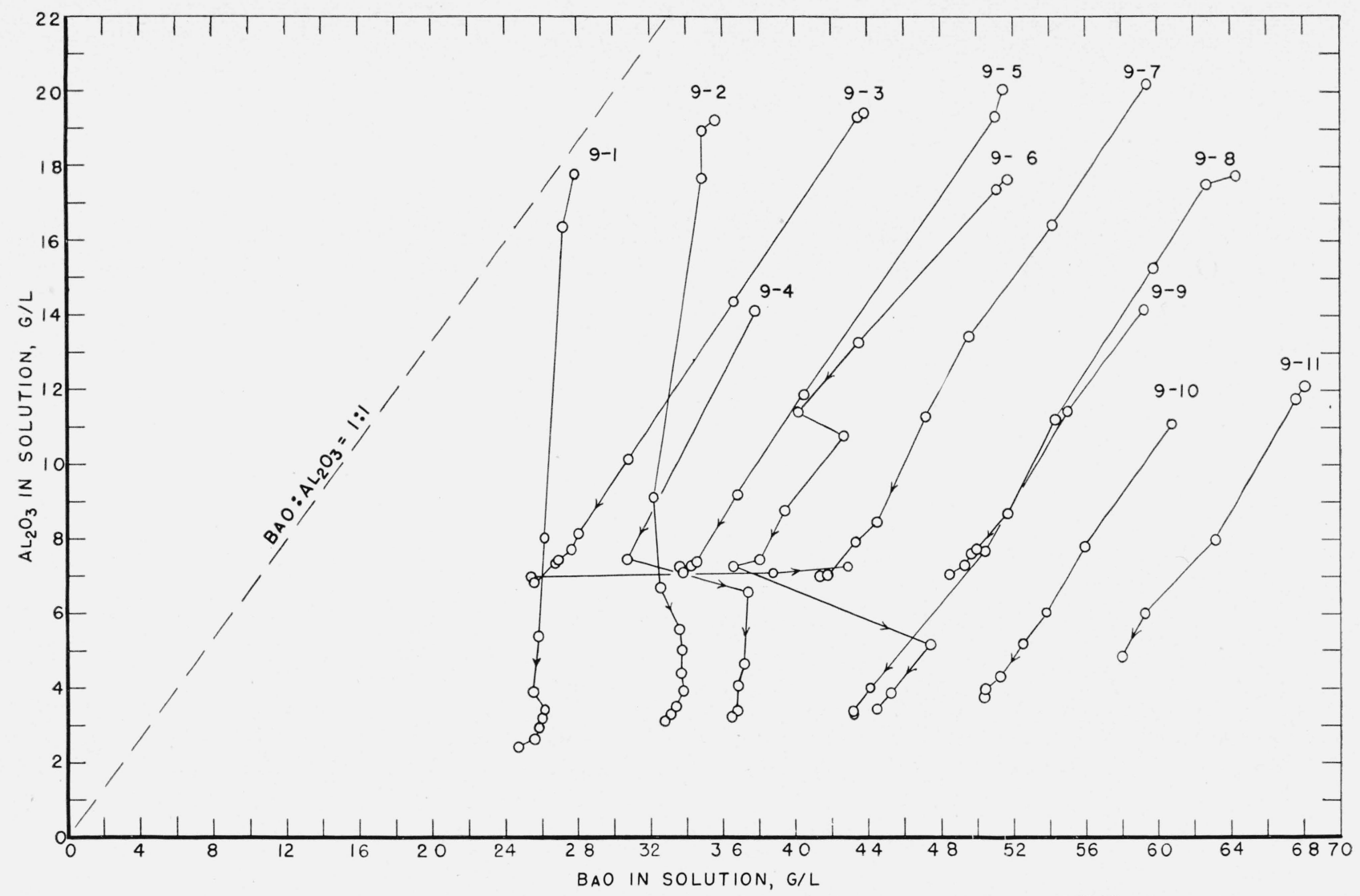

Figure 9. Precipitation from supersaturated barium aluminate solutions at $30^{\circ} \mathrm{C}$.

days. Its subsequent re-solution is reflected in an inflection toward the right in the curve.

Solutions more basic than No. 9-2 behaved differently. Experiments 9-3, 9-5, 9-6, 9-7, and 9-8 precipitated $7 \mathrm{BaO} \cdot 6 \mathrm{Al}_{2} \mathrm{O}_{3} \cdot 36 \mathrm{H}_{2} \mathrm{O}$ as the initial solid phase, followed by simultaneous disappearance of this phase and precipitation of $\mathrm{BaO} \cdot \mathrm{Al}_{2} \mathrm{O}_{3} .7 \mathrm{H}_{2} \mathrm{O}$. In $9-4,9-9$, and 9-10, the latter hydrate was the initial phase to separate out. It will be noted that in this latter group the initial concentration of $\mathrm{Al}_{2} \mathrm{O}_{3}$ was below $15 \mathrm{~g}$ /liter in each case. No. 9-6 is exceptional in that the inversion from $7 \mathrm{BaO} \cdot 6 \mathrm{Al}_{2} \mathrm{O}_{3} \cdot 36 \mathrm{H}_{2} \mathrm{O}$ to $\mathrm{BaO} . \mathrm{Al}_{2} \mathrm{O}_{3} .7 \mathrm{H}_{2} \mathrm{O}$ was accompanied by an abrupt change in direction of the concentration curve. For some unknown reason, the other members of the series failed to show this break, though 9-7 and 9-8 do show a more gradual change in slope, which may be attributed to the same reaction.

Experiment 9-4 is of interest in that it exhibits complete hydrolysis of the $\mathrm{BaO} \cdot \mathrm{Al}_{2} \mathrm{O}_{3} \cdot 7 \mathrm{H}_{2} \mathrm{O}$ first formed, with a corresponding change in concentration of the solution. The same is true of No. 9-3, except that in this case the hydrolosis was still incomplete when the experiment was terminated after 8 mos. Experiment 9-6 underwent an analogous change in concentration, but in this case $\mathrm{BaO} \cdot \mathrm{Al}_{2} \mathrm{O}_{3} \cdot 4 \mathrm{H}_{2} \mathrm{O}$ was precipitated along with the alumina. In 9-9 and 9-10 these two phases were also coprecipitated, but the hydrated alumina was present only in small amount, insufficient to cause any deflection of the concentration curve. Experiments 9-3, 9-5, 9-7, and 9-8 appear to have reached equilibrium at about $7 \mathrm{~g}$ of $\mathrm{Al}_{2} \mathrm{O}_{3}$ per liter, but it will be noted that these experiments were terminated after 7 mos or less. This group was started as the investigation was nearing completion, and their study was necessarily abbreviated. It should be clear from the previous discussion, however, that this apparent equilibrium is metastable, and it may reasonably be assumed that on longer standing, this group would have behaved as did the other members of the series.

Experiment 9-11 contained an excess of $\mathrm{Ba}(\mathrm{OH})_{2 .-}$ $8 \mathrm{H}_{2} \mathrm{O}$ present as a solid phase. The first new phase observed was $\mathrm{BaO} . \mathrm{Al}_{2} \mathrm{O}_{3} .4 \mathrm{H}_{2} \mathrm{O}$, rather than the heptahydrate. It is worthy of note that even in contact with excess barium hydroxide, the hydrate that was first precipitated was a monobarium compound.

The results of the above experiments and of a number of others involving precipitation from supersaturated solution may be generalized as follows: (1) Solutions containing less than $36 \mathrm{~g}$ of $\mathrm{BaO}$ per liter (approximately) precipitate amorphous hydrated alumina, together with some adsorbed $\mathrm{BaO}$. The rate of precipitation from the more concentrated solutions is fairly rapid, but from solutions less concentrated it may be extremely slow. The stable product is gibbsite. (2) Solutions containing more than $36 \mathrm{~g}$ of $\mathrm{BaO}$ per liter (approximately) precipitate one of 
the hydrated barium aluminates. In this more basic region the concentration of alumina determines which aluminate precipitates first. Above $15 \mathrm{~g}$ of $\mathrm{Al}_{2} \mathrm{O}_{3}$ per liter (very roughly) the first phase to appear is $7 \mathrm{BaO} .6 \mathrm{Al}_{2} \mathrm{O}_{3} .36 \mathrm{H}_{2} \mathrm{O}$; below that concentration the initial solid phase is $\mathrm{BaO} \cdot \mathrm{Al}_{2} \mathrm{O}_{3} \cdot 7 \mathrm{H}_{2} \mathrm{O}$. (3) $7 \mathrm{BaO}$. $6 \mathrm{Al}_{2} \mathrm{O}_{3} \cdot 36 \mathrm{H}_{2} \mathrm{O}$ is relatively unstable and soon disappears with the formation of either hydrated alumina, $\mathrm{BaO} \cdot \mathrm{Al}_{2} \mathrm{O}_{3} .7 \mathrm{H}_{2} \mathrm{O}$, or $\mathrm{BaO} \cdot \mathrm{Al}_{2} \mathrm{O}_{3} \cdot 4 \mathrm{H}_{2} \mathrm{O}$, depending on the concentration of $\mathrm{BaO}$ in the solution. (4) $\mathrm{BaO} \cdot \mathrm{Al}_{2} \mathrm{O}_{3} \cdot 7 \mathrm{H}_{2} \mathrm{O}$ is metastable and eventually disappears with formation of either hydrated alumina or $\mathrm{BaO} \cdot \mathrm{Al}_{2} \mathrm{O}_{3} .4 \mathrm{H}_{2} \mathrm{O}$ or both.

\section{Phase equilibria in the system $\mathrm{BaO}-\mathrm{Al}_{2} \mathrm{O}_{3}-\mathrm{H}_{2} \mathrm{O}$ at $30^{\circ} \mathrm{C}$}

From the data given in the preceding sections, it is possible to construct the greater part of the phase equilibrium diagram for the system $\mathrm{BaO}-\mathrm{Al}_{2} \mathrm{O}_{3}-\mathrm{H}_{2} \mathrm{O}$ at $30^{\circ} \mathrm{C}$. The equilibrium concentrations and the corresponding solid phases are listed in table 10 . In order to complete the diagram, it was necessary to study the solubilities of two additional compounds, namely, gibbsite $\left(\mathrm{Al}_{2} \mathrm{O}_{3} .3 \mathrm{H}_{2} \mathrm{O}\right)$ and barium hydroxide octahydrate $\left(\mathrm{Ba}(\mathrm{OH})_{2} .8 \mathrm{H}_{2} \mathrm{O}\right)$. Gibbsite was treated with barium hydroxide solutions in the manner previously described in connection with the aluminates. Analyses were made at intervals for a period of 8 to $9 \mathrm{mos}$, at the end of which time the concentrations had remained substantially constant for 3 mos. The barium hydroxide curve was established in part by experiments described above. Two additional points were obtained by determining the solubility of recrystallized barium hydroxide octahydrate in water and in a barium aluminate solution containing $1.42 \mathrm{~g}$ of $\mathrm{Al}_{2} \mathrm{O}_{3}$ per liter. In these experiments equilibrium was attained quickly, but because of the high temperature coefficient of solubility and the lack of high-precision temperature control it was necessary to make repeated analyses and use average values. The equilibrium data obtained in these two series of experiments are included in table 10 .

TABLE 10. Concentration of barium aluminate solutions in stable or metastable equilibrium with solid phases at $30^{\circ} \mathrm{C}$

\begin{tabular}{|c|c|c|c|c|}
\hline \multirow{2}{*}{$\begin{array}{l}\text { Experi- } \\
\text { ment }\end{array}$} & \multicolumn{2}{|c|}{$\begin{array}{l}\text { Concentra- } \\
\text { tion of solu- } \\
\text { tion }\end{array}$} & \multirow{2}{*}{ Solid phases present } & \multirow{2}{*}{$\begin{array}{l}\text { Direction of approach } \\
\text { to equilibrium }\end{array}$} \\
\hline & $\mathrm{Al}_{2} \mathrm{O}_{3}$ & $\mathrm{BaO}$ & & \\
\hline $\begin{array}{l}10-1 \\
10-2 \\
10-3 \\
10-4 \\
10-5 \\
10-6 \\
10-7 \\
10-8 \\
10-9 \\
10-10 \\
10-11\end{array}$ & $\begin{array}{r}\text { g/liter } \\
0.20 \\
.39 \\
.70 \\
.88 \\
1.06 \\
1.40 \\
1.69 \\
2.00 \\
2.56 \\
2.69 \\
3.08\end{array}$ & $\begin{array}{c}\text { g/liter } \\
4.8 \\
9.7 \\
14.2 \\
19.0 \\
23.9 \\
29.1 \\
34.2 \\
38.8 \\
44.7 \\
49.6 \\
55.4\end{array}$ & 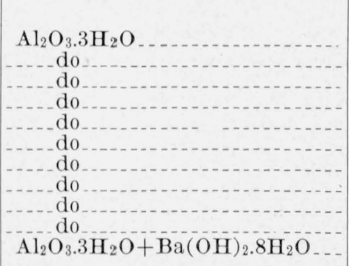 & $\begin{array}{l}\text { From undersaturation. } \\
\text { Do. } \\
\text { Do. } \\
\text { Do. } \\
\text { Do. } \\
\text { Do. } \\
\text { Do. } \\
\text { Do. } \\
\text { Do. } \\
\text { Do. } \\
\text { Do. }\end{array}$ \\
\hline $\begin{array}{l}5-2 \ldots \\
5-3 \ldots \\
5-4 \ldots \\
5-5 \\
5-6\end{array}$ & $\begin{array}{l}\text { 3. } 00 \\
2.83 \\
2.79 \\
2.90 \\
2.74\end{array}$ & $\begin{array}{l}12.5 \\
17.6 \\
22.0 \\
26.4 \\
31.6\end{array}$ & \begin{tabular}{l}
$\mathrm{BaO} \cdot \mathrm{Al}_{2} \mathrm{O}_{3} .4 \mathrm{H}_{2} \mathrm{O}+\mathrm{hyd} . \mathrm{Al}_{2} \mathrm{O}_{3}$ \\
$\quad \mathrm{~d} 0$ \\
\hdashline do
\end{tabular} & $\begin{array}{l}\text { Do. } \\
\text { Do. } \\
\text { Do. } \\
\text { Do. } \\
\text { Do. }\end{array}$ \\
\hline
\end{tabular}

TABLE 10. Concentration of barium aluminate solutions in stable or metastable equilibrium with solid phases at $30^{\circ} \mathrm{C}-$ Continued

\begin{tabular}{|c|c|c|c|c|}
\hline \multirow{2}{*}{$\begin{array}{l}\text { Experi- } \\
\text { ment }\end{array}$} & \multicolumn{2}{|c|}{$\begin{array}{c}\text { Concentra- } \\
\text { tion of solu- } \\
\text { tion }\end{array}$} & \multirow{2}{*}{ Solid phases present } & \multirow{2}{*}{$\begin{array}{l}\text { Direction of approach } \\
\text { to equilibrium }\end{array}$} \\
\hline & $\mathrm{Al}_{2} \mathrm{O}_{3}$ & $\mathrm{BaO}$ & & \\
\hline $10-21$ & $\begin{array}{l}\text { g/liter } \\
3.11\end{array}$ & $\begin{array}{c}\text { g/liter } \\
33.3\end{array}$ & $\mathrm{BaO}-\mathrm{Al}_{2} \mathrm{C}_{3} 4 \mathrm{H}_{2} \mathrm{O}+\mathrm{hvd} \mathrm{Al}_{2} \mathrm{O}_{3}$ & \\
\hline $10-22$ & 3.08 & $\begin{array}{l}50.0 \\
35.2\end{array}$ & $\mathrm{BaO}_{\mathrm{A}} \mathrm{Al}_{2} \mathrm{C}_{3} .4 \mathrm{H}_{2} \mathrm{O}+\mathrm{nyd} . \mathrm{Al}_{2} \mathrm{O}_{3--}$ & $\begin{array}{l}\text { From supersaturation. } \\
\text { Do. }\end{array}$ \\
\hline $10-23$ & 3.25 & 37.5 & do & Do. \\
\hline $5-7 \ldots$ & 2.68 & 40.7 & ...... do & From undersaturation. \\
\hline $9-9$ & 3.33 & 43. 2 & do & From supersaturation. \\
\hline $5-8$ & 2.74 & 45.4 & do & From undersaturation. \\
\hline $5-9$ & 2.74 & 49.9 & $\mathrm{BaO} . \mathrm{Al}_{2} \mathrm{O}_{3} .4 \mathrm{H}_{2} \mathrm{O}$ & Do. \\
\hline $10-12 \ldots$ & 2.86 & 55.6 & $\begin{array}{l}\mathrm{BaO} . \mathrm{Al}_{2} \mathrm{O}_{3} .4 \mathrm{H}_{2} \mathrm{O}+\mathrm{Ba}(\mathrm{OH})_{2} \\
\underset{\mathrm{H}_{2} \mathrm{O}}{ }\end{array}$ & Do. \\
\hline $8-3$ & 5. 20 & 32.4 & $2 \mathrm{BaO} . \mathrm{Al}_{2} \mathrm{O}_{3} .5 \mathrm{H}_{2} \mathrm{O}+$ hyd. $\mathrm{Al}_{2} \mathrm{O}_{3}$ & Do. \\
\hline-4 . & 4. 20 & 37.8 & do & Do. \\
\hline & 3.35 & 43.6 & ...... do _. & Do. \\
\hline $8-6$. & 2.95 & 48. 1 & ...... do & Do. \\
\hline 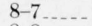 & 2.80 & 52.0 & ..... do & Do. \\
\hline $8-8$ & 2.75 & 53.7 & -.... do & Do. \\
\hline $10-13$ & 2. 70 & 55.4 & $\begin{array}{l}2 \mathrm{BaO}_{2} \mathrm{Al}_{2} \mathrm{O}_{3} .5 \mathrm{H}_{2} \mathrm{O}+\mathrm{Ba}(\mathrm{OH})_{2} . \\
\quad 8 \mathrm{H}_{2} \mathrm{O} .\end{array}$ & Do. \\
\hline $6-2$ & 7. 44 & 20.0 & $\mathrm{BaO} . \mathrm{Al}_{2} \mathrm{O}_{3} .7 \mathrm{H}_{2} \mathrm{O}$ & Do. \\
\hline $10-1$ & 7.42 & 22.8 & _.... do do & Do. \\
\hline $9-3$. & 6.89 & 25.6 & ..... do & From supersaturation. \\
\hline $6-3:$ & 7.12 & 27.8 & $\ldots$ do & From undersaturation. \\
\hline $9-4$. & 7. 48 & 30.7 & ...... do & From supersaturation. \\
\hline $9-5$ & 7. 20 & 33.3 & .... do & Do. \\
\hline $6-4$ & 7. 33 & 34.4 & ...... do & From undersaturation. \\
\hline $9-6$ & 7. 24 & 36.6 & ...... do ... & From supersaturation. \\
\hline $10-15$ & 7. 20 & 37.3 & ...... do & From undersaturation. \\
\hline $6-5$ & 7.45 & 41. 4 & ..... do & Do. \\
\hline $9-7$ & 7. 10 & 41.9 & ...... do & From supersaturation. \\
\hline $10-16$ & 7. 16 & 43.6 & ..... do & From undersaturation. \\
\hline $10-24$ & 6.95 & 46.3 & ..... do & From supersaturation. \\
\hline $9-8$ & 7. 32 & 49. 2 & _.... do & Do. \\
\hline $6-6$ & 7. 10 & 50.3 & ..... do & From undersaturation. \\
\hline $10-2$ & 7. 16 & 54.2 & ..... do & From supersaturation. \\
\hline $6-7$ & 7.78 & 55.3 & ..... do & From undersaturation. \\
\hline $10-17$ & 7.65 & 57.7 & do & Do. \\
\hline $10-18$ & 7.80 & 62.2 & $\begin{array}{l}\mathrm{BaO} \cdot \mathrm{Al}_{2} \mathrm{O}_{3} .7 \mathrm{H}_{2} \mathrm{O}+\mathrm{Ba}(\mathrm{OH})_{2} . \\
\quad 8 \mathrm{H}_{2} \mathrm{O} .\end{array}$ & Do. \\
\hline $7-2$ & 11.80 & 29.5 & $\underset{\mathrm{Al}_{2} \mathrm{O}_{3} .}{\mathrm{BaO}} .6 \mathrm{Al}_{2} \mathrm{O}_{3}, 36 \mathrm{H}_{2} \mathrm{O}$ thyd. & Do. \\
\hline $7-3$ & 12. 20 & 35. 2 & $7 \mathrm{BaO} .6 \mathrm{Al}_{2} \mathrm{O}_{3} .36 \mathrm{H}_{2} \mathrm{O} \ldots$ & Do. \\
\hline & 11. 14 & 42. 1 & ..... do & Do. \\
\hline & 11.60 & 46. 4 & do & Do. \\
\hline & 11.00 & 52.7 & $\underset{ }{7 \mathrm{BaO} \cdot 6 \mathrm{Al}_{2} \mathrm{O}_{3}} \cdot 36 \mathrm{H}_{2} \mathrm{O}+\mathrm{BaO}$ & Do. \\
\hline $7-7$ & 9. 90 & 56.5 & $7 \mathrm{BaO} .6 \mathrm{Al}_{2} \mathrm{O}_{3} .36 \mathrm{H}_{2} \mathrm{O}$ & Do. \\
\hline & 10.20 & 66. 1 & $\begin{array}{l}7 \mathrm{BaO}^{\mathrm{BaO}} \cdot 6 \mathrm{Al}_{2} \mathrm{O}_{3} \cdot 36 \mathrm{H}_{2} \mathrm{O}+\mathrm{BaO} \\
\mathrm{Al}_{2} \mathrm{O}_{3} \cdot 4 \mathrm{H}_{2} \mathrm{O}+\mathrm{Ba}(\mathrm{OH})_{2} \cdot 8 \mathrm{H}_{2} \mathrm{O}\end{array}$ & Do. \\
\hline $10-19$ & $(0)$ & 52.9 & $\mathrm{Ba}(\mathrm{OH})_{2} .8 \mathrm{H}_{2} \mathrm{O}$ & Do. \\
\hline & 1.42 & 54.1 & ... do & Do. \\
\hline
\end{tabular}

Also included are a number of points representing equilibrium (metastable) approached from supersaturation rather than undersaturation. These points are shown as filled triangles in figure 10, in order to distinguish them from the others. It will be noted that there is fair agreement between the two methods of approach in the case of $\mathrm{BaO} \cdot \mathrm{Al}_{2} \mathrm{O}_{3} \cdot 7 \mathrm{H}_{2} \mathrm{O}$. In the case of the tetrahydrate, however, the values obtained from the precipitation experiments are erratic and are generally higher than those obtained from solution experiments. The reason for this is not known. No corresponding figures are given for $7 \mathrm{BaO} .6 \mathrm{Al}_{2} \mathrm{O}_{3} .36 \mathrm{H}_{2} \mathrm{O}$, as there was no arrest in concentration during precipitation in this range. Further, there are no precipitation data for $2 \mathrm{BaO} \cdot \mathrm{Al}_{2} \mathrm{O}_{3}$.$5 \mathrm{H}_{2} \mathrm{O}$ because this phase was not obtained by precipitation at $30^{\circ}$.

No attempt was made to determine the solubility curve of amorphous hydrated alumina, partly because it is difficult to prepare this material free of interfering ions, and partly because it was believed 


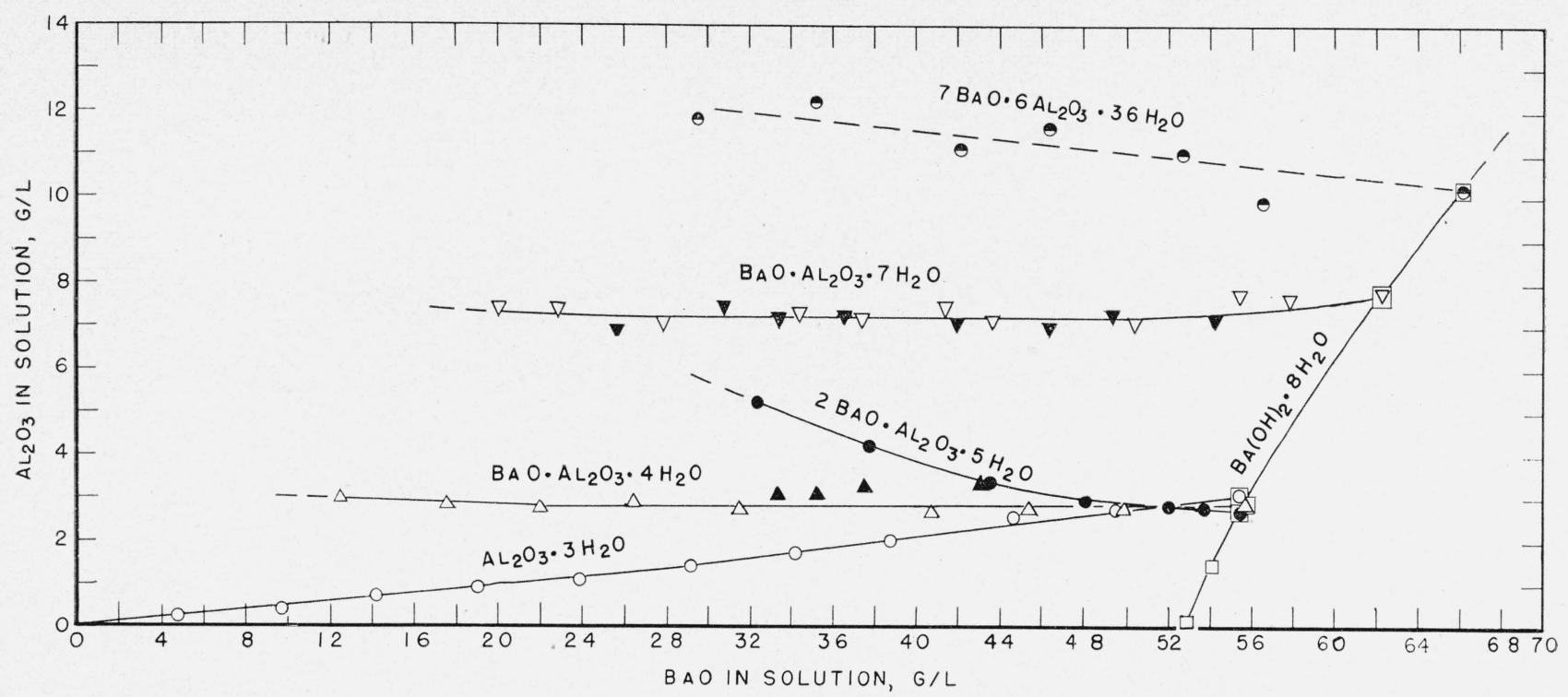

FIGURE 10. Concentration of barium aluminate solutions in stable or metastable equilibrium with solid phases at $30^{\circ}$ C.

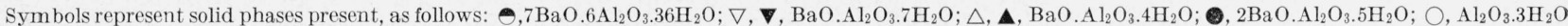

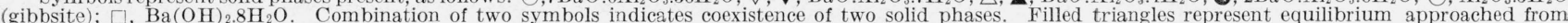
supersaturation. Other points represent equilibrium approached from undersaturation.

that such a curve would be dependent on the mode of preparation, hence not very significant. No tests were made with any of the crystalline forms of hydrated alumina other than gibbsite, and, as mentioned above, no work was done on the compound $\mathrm{BaO} .6 \mathrm{Al}_{2} \mathrm{O}_{3}$.

Solubility curves for $\mathrm{BaO} \cdot \mathrm{Al}_{2} \mathrm{O}_{3} \cdot \mathrm{H}_{2} \mathrm{O}$ and $\mathrm{BaO}$.$\mathrm{Al}_{2} \mathrm{O}_{3} \cdot 2 \mathrm{H}_{2} \mathrm{O}$ are likewise missing. As shown in section III, 4 and III, 5, these hydrates, both of which were prepared hydrothermally, are unstable in contact with barium hydroxide solutions at $30^{\circ} \mathrm{C}$, and hence cannot be said to possess solubility curves at this temperature.

Figure 10 is the phase equilibrium diagram of the system $\mathrm{BaO}-\mathrm{Al}_{2} \mathrm{O}_{3}-\mathrm{H}_{2} \mathrm{O}$ at $30^{\circ} \mathrm{C}$, complete except as noted above. The stable phases are gibbsite and barium hydroxide octahydrate, and possibly, over a narrow range, $2 \mathrm{BaO} \cdot \mathrm{Al}_{2} \mathrm{O}_{3} .5 \mathrm{H}_{2} \mathrm{O}$ or $\mathrm{BaO} \cdot \mathrm{Al}_{2} \mathrm{O}_{3}$.$4 \mathrm{H}_{2} \mathrm{O}$. The other phases for which curves are shown are metastable throughout their entire range. Nevertheless, because of the slowness of transition from one phase to another, it is possible to trace a definite solubility curve for each of the solid phases, except $7 \mathrm{BaO} .6 \mathrm{Al}_{2} \mathrm{O}_{3} \cdot 36 \mathrm{H}_{2} \mathrm{O}$ and amorphous hydrated alumina. A dotted curve has been drawn to represent the approximate solubilities of the former.

It is apparent from figure 10 that there is some uncertainty as to what is the stable solid phase over a short range (50 to $56 \mathrm{~g}$ of $\mathrm{BaO}$ per liter, approximately). On the basis of the data given, it appears that there is a point at $2.8 \mathrm{~g}$ of $\mathrm{Al}_{2} \mathrm{O}_{3}$ and $52.0 \mathrm{~g}$ of $\mathrm{BaO}$ per liter at which gibbsite and $2 \mathrm{BaO} \cdot \mathrm{Al}_{2} \mathrm{O}_{3} .5 \mathrm{H}_{2} \mathrm{O}$ are in equilibrium, and another point at $2.7 \mathrm{~g}$ of $\mathrm{Al}_{2} \mathrm{O}_{3}$ and $55.6 \mathrm{~g}$ of $\mathrm{BaO}$ per liter at which $2 \mathrm{BaO}$.$\mathrm{Al}_{2} \mathrm{O}_{3} .5 \mathrm{H}_{2} \mathrm{O}$ and $\mathrm{Ba}(\mathrm{OH})_{2} .8 \mathrm{H}_{2} \mathrm{O}$ are the stable solid phases. However, the solubilities of the three aluminous phases are so close together in this area, and the reactions leading to equilibrium are so slow, that the stability relations here indicated cannot be considered definitely established. Additional experiments a few degrees above and below $30^{\circ} \mathrm{C}$ might assist in clarifying the question.

\section{Equilibria at Other Temperatures}

A few experiments were conducted at temperatures other than $30^{\circ} \mathrm{C}$. In particular, sufficient work was done on the solubilities of $\mathrm{BaO} \cdot \mathrm{Al}_{2} \mathrm{O}_{3} \cdot 7 \mathrm{H}_{2} \mathrm{O}$ and $\mathrm{Ba}(\mathrm{OH})_{2} .8 \mathrm{H}_{2} \mathrm{O}$ at $25^{\circ} \mathrm{C}$ to establish at least a portion of the curves for these compounds. As might be expected, they are parallel to the curves at $30^{\circ} \mathrm{C}$, but at lower concentrations. The solubility of $\mathrm{Ba}(\mathrm{OH})_{2} .8 \mathrm{H}_{2} \mathrm{O}$ was found to be equivalent to $42.7 \mathrm{~g}$ of $\mathrm{BaO}$ per liter at $25^{\circ} \mathrm{C}$, and the point at which the two solid phases coexist was placed approximately at $6.8 \mathrm{~g}$ of $\mathrm{Al}_{2} \mathrm{O}_{3}$ and $52.0 \mathrm{~g}$ of $\mathrm{BaO}$ per liter. The solubility of $\mathrm{Ba}(\mathrm{OH})_{2} .8 \mathrm{H}_{2} \mathrm{O}$ at $50^{\circ} \mathrm{C}$, expressed in terms of $\mathrm{BaO}$, was found to be about $102 \mathrm{~g}$ /liter. This figure is not exact, as the temperature control was probably no closer than $1 \mathrm{deg}$, but is given merely to indicate the magnitude of the temperature coefficient of solubility. At this temperature $\mathrm{BaO}$.$\mathrm{Al}_{2} \mathrm{O}_{3} .7 \mathrm{H}_{2} \mathrm{O}$ is rapidly converted to $\mathrm{BaO} \cdot \mathrm{Al}_{2} \mathrm{O}_{3} .4 \mathrm{H}_{2} \mathrm{O}$. No equilibrium measurements were made for the tetrahydrate at temperatures other than $30^{\circ} \mathrm{C}$.

As mentioned in the introduction, a diagram of phase equilibria in this system at $20^{\circ} \mathrm{C}$ has been published by Malquori [16]. With due allowance for the difference in temperature, it still is difficult to reconcile his diagram with that given in figure 10 . In particular, Malquori shows only two barium aluminate hydrates, $2 \mathrm{BaO} . \mathrm{Al}_{2} \mathrm{O}_{3} .5 \mathrm{H}_{2} \mathrm{O}$ and one that he designates $\mathrm{BaO} \cdot \mathrm{Al}_{2} \mathrm{O}_{3} \cdot 6 \mathrm{H}_{2} \mathrm{O}$. The latter, which we may assume to be identical with the compound referred to herein as the heptahydrate, is indicated to be the stable phase along a curve extending approx- 
imately from $2 \mathrm{~g}$ of $\mathrm{Al}_{2} \mathrm{O}_{3}$ and $12 \mathrm{~g}$ of $\mathrm{BaO}$ to $6 \mathrm{~g}$ of $\mathrm{Al}_{2} \mathrm{O}_{3}$ and $22 \mathrm{~g}$ of $\mathrm{BaO}$ per liter. This is considerably above the curve shown in figure 10 for gibbsite $\left(\mathrm{Al}_{2} \mathrm{O}_{3} .3 \mathrm{H}_{2} \mathrm{O}\right)$, and the latter very probably would be found to have a lower solubility at $20^{\circ}$ than at $30^{\circ}$. It is believed, therefore, that Malquori's curve does not represent stable equilibrium.

\section{Effect of Impurities}

As is well known, barium hydroxide solutions rapidly absorb carbon dioxide from the air, with the formation of barium carbonate. Preliminary experiments indicated that this reaction would not seriously affect the results obtained in this study. The carbonate formed is practically insoluble in barium hydroxide, and thus would be expected to have no effect on equilibrium relations. Samples for analysis generally were taken with a pipette, leaving little chance for carbonation during sampling. Any carbonate formed on the microscope slide was readily distinguished from other phases by its high birefringence. Periodic opening of flasks for sampling resulted in visible carbonation, but the total amount was negligible, as evidenced by the constancy of concentration of the solution after attainment of equilibrium.

More serious contamination was introduced by the solvent action of the barium hydroxide solutions on the glass containers. In order to estimate the extent of the attack, a large number of silica determinations were made on reaction mixtures that had stood for varying periods of time. The amount of silica found in solution was invariably small, usually about 2 or $3 \mathrm{mg} /$ liter. The amount of silica in the solid residue, however, was considerable in flasks that had been standing a long time, but there was no apparent uniformity as to amount. For example, the molar ratio of $\mathrm{SiO}_{2}$ to $\mathrm{Al}_{2} \mathrm{O}_{3}$ was found to be 0.03 in the precipitate from one solution (not listed above), and 0.84 in the precipitate from another of very nearly the same concentration. Both had stood $2 \mathrm{yr}$, and in both cases the total quantity of solid was slight, having precipitated from relatively dilute solution. In most cases the amount of precipitate was much greater and the percentage of $\mathrm{SiO}_{2}$ correspondingly smaller. For example, the residue from mixture 9-1, filtered off after 6 mo, contained 0.01 mole of $\mathrm{SiO}_{2}$ per mole of $\mathrm{Al}_{2} \mathrm{O}_{3}$. The silica was found to be present in the amorphous phase, not in the crystalline $\mathrm{BaO} \cdot \mathrm{Al}_{2} \mathrm{O}_{3} .4 \mathrm{H}_{2} \mathrm{O}$, which was in most cases the other phase present in the precipitate after long standing. This was shown in a number of cases by separation of the precipitate into fine and coarse fractions, followed by analysis of each. This fact may be significant in connection with the observed presence of the amorphous phase in even the most basic mixtures, in the region where the equilibrium diagram indicates that one of the crystalline hydrates should be the stable phase. It is probable that in this case the observed amorphous material (always small in amount) is either a barium silicate hydrate or a barium aluminosilicate hydrate, in either case relatively insoluble.
The presence of silica in the precipitate is positive evidence of the solvent action of the solutions on the glass containers. It must be assumed, therefore, that the other constituents of the glass, chiefly soda and boron trioxide, likewise were present as contaminants. No tests, however, were made for these constituents. It is reasonable to suppose that the soda would remain in solution and that it might therefore have some effect on the equilibrium concentrations. From the fact that no progressive change in equilibrium concentration with time was observed, it is believed that this factor was of negligible significance.

\section{Comparison of Barium and Calcium Aluminates}

It was brought out in section III, 2 that anhydrous monobarium aluminate possesses the property of setting to a hard mass after being mixed with water. The same phenomenon was observed with anhydrous tribarium aluminate as well. It was also shown that both of these compounds, when mixed with water, form solutions that are highly supersaturated with respect to certain hydrated products. This is in agreement with the well-known theory of Le Chatelier [18] that "the crystallization which accompanies the set of all of the bodies hardening upon contact with water results from the previous production of a supersaturated solution". Le Chatelier and later investigators have shown that this is true of the calcium aluminates, so that in this respect it may be said that there is a similarity in behavior between the aluminates of barium and of calcium. There is a further similarity in that both $3 \mathrm{BaO} \cdot \mathrm{Al}_{2} \mathrm{O}_{3}$ and $3 \mathrm{CaO} \cdot \mathrm{Al}_{2} \mathrm{O}_{3}$ react very vigorously with water, whereas the corresponding $1: 1$ aluminates react much more slowly. Beyond this, however, it is immediately apparent that the aluminates of barium are quite different from those of calcium. The former are much more soluble and form an entirely different series of hydration products. As is well known, the calcium aluminates produce an isometric hydrate, $3 \mathrm{CaO} \cdot \mathrm{Al}_{2} \mathrm{O}_{3} .6 \mathrm{H}_{2} \mathrm{O}$, as well as a crystalline product consisting of hexagonal plates in which the ratio of $\mathrm{CaO}$ to $\mathrm{Al}_{2} \mathrm{O}_{3}$ is either $2: 1$ or $4: 1$ or an intermediate value. Neither type of product was observed with the barium aluminates. These, on the other hand, yield a series of hydrates in which the ratio of $\mathrm{BaO}$ to $\mathrm{Al}_{2} \mathrm{O}_{3}$ is $1: 1$, or nearly so, together with a single more basic hydrate, $2 \mathrm{BaO} . \mathrm{Al}_{2} \mathrm{O}_{3} .5 \mathrm{H}_{2} \mathrm{O}$, which in no way resembles the dicalcium aluminate hydrate. Only in the least basic region of the phase diagram are the systems $\mathrm{BaO}-\mathrm{Al}_{2} \mathrm{O}_{3}-\mathrm{H}_{2} \mathrm{O}$ and $\mathrm{CaO}$ $\mathrm{Al}_{2} \mathrm{O}_{3}-\mathrm{H}_{2} \mathrm{O}$ similar. Here, over a short range in the latter system, and over a much longer range in the former, gibbsite is the stable solid phase.

\section{Summary}

On the basis of the experiments described above, and subject to the experimental conditions, the following conclusions are presented:

1. Monobarium aluminate is hydrolyzed by water, with precipitation of hydrated alumina. 
2. Monobarium aluminate dissolves in barium hydroxide solutions with precipitation first of $7 \mathrm{BaO} .6 \mathrm{Al}_{2} \mathrm{O}_{3} .36 \mathrm{H}_{2} \mathrm{O}$, subsequently of $\mathrm{BaO} \cdot \mathrm{Al}_{2} \mathrm{O}_{3}$.$7 \mathrm{H}_{2} \mathrm{O}$ in the less basic and $\mathrm{BaO} \cdot \mathrm{Al}_{2} \mathrm{O}_{3} \cdot 4 \mathrm{H}_{2} \mathrm{O}$ in the more basic solutions.

3. Tribarium aluminate is rapidly hydrolyzed by water, with precipitation of $\mathrm{Ba}(\mathrm{OH})_{2} .8 \mathrm{H}_{2} \mathrm{O}, \mathrm{BaO}$.$\mathrm{Al}_{2} \mathrm{O}_{3} .7 \mathrm{H}_{2} \mathrm{O}$, and, subsequently, $2 \mathrm{BaO} . \mathrm{Al}_{2} \mathrm{O}_{3} .5 \mathrm{H}_{2} \mathrm{O}$.

4. All the hydrated barium aluminates dissolve in water and are hydrolyzed, with precipitation of hydrated alumina.

5. The hydrated barium aluminates dissolve in barium hydroxide solutions with eventual precipitation of the equilibrium solid phases, but frequently with preliminary separation of metastable intermediate solid phases.

6. The stable solid phases in the system $\mathrm{BaO}-\mathrm{Al}_{2} \mathrm{O}_{3}$ $\mathrm{H}_{2} \mathrm{O}$ at $30^{\circ} \mathrm{C}$ are: (a) gibbsite $\left(\mathrm{Al}_{2} \mathrm{O}_{3} \cdot 3 \mathrm{H}_{2} \mathrm{O}\right)$ over a range from approximately zero concentration to about $52 \mathrm{~g}$ of $\mathrm{BaO}$ and $2.8 \mathrm{~g}$ of $\mathrm{Al}_{2} \mathrm{O}_{3}$ per liter; (b) $\mathrm{Ba}(\mathrm{OH})_{2} .8 \mathrm{H}_{2} \mathrm{O}$ from $52.9 \mathrm{~g}$ of $\mathrm{BaO}$ and zero $\mathrm{Al}_{2} \mathrm{O}_{3}$ to about $55.5 \mathrm{~g}$ of $\mathrm{BaO}$ and $2.7 \mathrm{~g}$ of $\mathrm{Al}_{2} \mathrm{O}_{3}$ per liter; (c) probably $2 \mathrm{BaO} \cdot \mathrm{Al}_{2} \mathrm{O}_{3} .5 \mathrm{H}_{2} \mathrm{O}$ (but possibly $\mathrm{BaO}$.$\mathrm{Al}_{2} \mathrm{O}_{3} \cdot 4 \mathrm{H}_{2} \mathrm{O}$ or gibbsite) over the short range from $52 \mathrm{BaO}$ and $2.8 \mathrm{Al}_{2} \mathrm{O}_{3}$ to $55.5 \mathrm{BaO}$ and $2.7 \mathrm{Al}_{2} \mathrm{O}_{3}$.

7. $7 \mathrm{BaO} .6 \mathrm{Al}_{2} \mathrm{O}_{3} \cdot 36 \mathrm{H}_{2} \mathrm{O}$ is a metastable phase, not sufficiently stable to permit an accurate determination of its solubility.

8. $\mathrm{BaO} \cdot \mathrm{Al}_{2} \mathrm{O}_{3} \cdot 7 \mathrm{H}_{2} \mathrm{O}$ is also metastable, but it may exist in contact with solution for several months.

9. $\mathrm{BaO} \cdot \mathrm{Al}_{2} \mathrm{O}_{3} \cdot 4 \mathrm{H}_{2} \mathrm{O}$ is likewise metastable over the greater part, if not all, of its range, but its stability is greater than that of the higher hydrates.
10. $2 \mathrm{BaO} \cdot \mathrm{Al}_{2} \mathrm{O}_{3} .5 \mathrm{H}_{2} \mathrm{O}$ resembles $\mathrm{BaO} \cdot \mathrm{Al}_{2} \mathrm{O}_{3} \cdot 4 \mathrm{H}_{2} \mathrm{O}$ in its degree of stability in the metastable range.

11. No hydrate more basic than $2 \mathrm{BaO} \cdot \mathrm{Al}_{2} \mathrm{O}_{3} \cdot 5 \mathrm{H}_{2} \mathrm{O}$ was found.

\section{References}

[1] R. Stumper, Chimie \& industrie 22, 1067 to 83 (1929).

2] G. Grube and G. Heintz, Z. Electrochem. 41, 797 (1935).

[3] K. Akiyama, Z. Kajima, and H. Aiba, J. Soc. Chem. Ind. (Japan) 41, 218 (1938), and 42, 145 (1939); abstr. in Chem Abstr. 33, 325 and 7497 (1939).

[4] V. F. Zhuravlev, Tsement 1939, No. 8, 41; abstract in Chem. Abstr. 35, 595 (1941).

[5] F. L. Hunt and M. Temin, Radiology (Feb. 1927).

[6] G. W. Morey, U. S. Patent 1,688,054 (1928).

[7] H. V. Wartenburg and H. J. Reusch, Z. anorg. allgem. Chem. 20\%, 1 (1932).

[8] S. Wallmark and A. Westgren, Arkiv. Kemi, Mineral, Geol. 12B, No. 35 (1937).

[9] N. A. Toropov, Compt. rend. acad. sci. URSS 1935, 150.

[10] N. A. Toropov and M. M. Stukalova, Compt. rend. acad. sci. URSS, 24, 459 (1939).

[11] N. A. Toropov and M. M. Stukalova, Compt rend. acad. sci. URSS, 27,974 (1940).

[12] E. T. Carlson and L. S. Wells, J. Research NBS 41, 103 (1948) RP1908.

[13] E. Beckman, J. prakt. Chem. [2] 26, 385 and 474; 27, 126 (1883).

[14] G. Maekawa, J. Soc. Chem. Ind. (Japan) 44, 912 (1941); abstr. in Chem. Abstr. 42, 2536 (1948).

[15] G. Maekawa, J. Soc. Chem. Ind. (Japan) 45, 130 (1942).

[16] G. Malquori, Gazz. chim. ital. 56, 51 (1926).

[17] G. Gallo, Ind. ital. del cemento 17, 123 (1947).

[18] H. Le Chatelier, Experimental researches on the constitution of hydraulic mortars (1887) (Translated by J. L. Mack, 1905).

[19] A. Braniski, Rev. matériaux construction trav. publ. (Ed. C), No. 404, 154 (1949).

Washington, June 2, 1950.

\title{
Permeability of Glass Wool and Other Highly Porous Media
}

\section{By Arthur S. Iberall}

\begin{abstract}
An elementary treatment is developed for the permeability of fibrous materials of high porosities, based on the drag of the individual filaments. It is believed that the same treatment is valid for other highly porous media. A brief historical review is given of theories relating the permeability to the structure of porous media. The applicability of the currently accepted permeability theory, based on the hydraulic radius, only to media of low porosities is discussed. Both approaches may be extended to permit approximate correlation for intermediate porosities. For fibrous materials of high porosity, it is shown that the effect of fluid inertia results in a permeability that varies with flow even at low Reynolds number. The permeability to gaseous flow is also shown to vary with the absolute gas pressure. This variation is appreciable when the molecular mean free path is of the same order of magnitude as the separation between filaments or particles in the medium. Data suitable for the design of linear flowmeters utilizing fibrous materials of high porosity are given, including data on the useful porosity range of fibrous media.
\end{abstract}

\section{Introduction}

During the war there arose a need in the Bureau of Aeronautics, Department of the Navy, for rapid procurement of equipment suitable for field tests of diluter-demand oxygen regulators, which are used

1 This paper is a theoretical abstract of a report to the Bureau of Aeronautics, Navy Department [1]. Figures in brackets indicate the literature references at the end of this paper. by flight personnel at high altitudes. Due to difficulties in procurement, and certain disadvantages in the convenient use of commercially available flowmeters for the measurement of gaseous flow, the development of a suitable flowmeter was undertaken. After some preliminary consideration, efforts were centered on the development of a constant-resistance flowmeter utilizing a porous medium as the flow- 